\title{
Osmanlı Tasvir Sanatında Görselin “Okunması”: İmgenin Ardındaki Hikâyeler (Şehir Oğlanları ve İstanbul'un Meşhur Kadınları)
}

\author{
Tülün Değirmenci*
}

Visual Reading or Reading with Images? Visuality and Orality in Ottoman Manuscript Culture (City Boys and Beautiful Women of Istanbul)

Abstract $\square$ The organic relationship between the text and image is the most distinctive feature of Islamic manuscript painting. However, there was a long-established tradition of making one-page album paintings that do not have any textual context related to the image. To capture the intended meaning of album paintings, we need to develop the study of "visual reading", just as their contemporary spectators did. Therefore, the oral literary context, in which these paintings were produced and consumed, becomes extremely important to acquire the iconography of visual codes repeated in many album paintings, probably had certain meanings approved in the collective memory of the society. In this respect, I will mostly focus on a group of album paintings depicting young males and females produced in $17^{\text {th }}$ century-Ottoman İstanbul. I will try to observe and the visual language of these album paintings in conjunction with the demographic, economic and political changes by the $17^{\text {th }}$ century. Specifically, the variations in contents and forms of oral and literate culture, in accordance with new forms and venues of socialization, will be the crucial point of my argument.

Keywords: Ottoman Manuscripts, $17^{\text {th }}$ Century Ottoman History, Album Paintings, Miniature, City Boys, Concubines.

Sözlü kültür çalışmalarının önemli isimlerinden biri olan Walter J. Ong "Bir görüntü, bin kelimeye değer” önermesi eğer doğruysa bunun bir deyiş olmasına ne gerek var diye sorar ve ardından bu sorusunu şöyle yanıtlar: "Çünkü bir görüntü, ancak belirli koşullarda bin kelimenin yerini tutar ki o da, görüntüyü

* Pamukkale Üniversitesi. Bu yazının her aşamasında yardımlarını esirgemeyen Seyfi Kenan'a en içten teşekkürlerimi sunarım. 
çevreleyen kelimeleri içeren bağlamdır." ${ }^{\text {B }}$ Burada Ong’un bahsettiği görüntüyü çevreleyen sözel bağlamın, daha çok simgelerle konuşmayı/anlatmayı seven ve çoğunlukla sözlü/sözel kültürün baskın olduğu bir toplum içinde üretilen/tüketilen İslâm tasvir sanatını anlamak üzere önemli çıkış noktalarından biri olabileceği kanısındayım.

Genel olarak İslâm sanatında, özel olarak da Osmanlı sanatında tasvir denince çoğunlukla elyazmaları içinde yer alan ve eşlik ettiği metni görsel dile aktaran kitap resimleri, popüler adıyla minyatürler akla gelir. Kitap resmini diğer resim türlerinden ayıran en önemli özelliklerinden biri metne bağlı olmasıdır. Bunun dışında özellikle 16. yüzyıl sonu ve 17. yüzyıl boyunca sıklıkla yapıldığı görülen, herhangi bir metne eşlik etmeyen -daha doğrusu fiziksel olarak etmeyen- tek yaprak albüm/murakka resimleri de İslâm tasvir sanatı geleneğinde epeyce yaygın bir şekilde karşımıza çıkar. Elyazma kitaplar içinde yer alan resimlerin ikonografik bağlamını çözümlemek için "en azından” belirli bir metin vardır. Ong'un deyimiyle, görüntüyü çevreleyen bağlam, bizzat yazılı olarak mevcuttur. Kuşkusuz burada da nakkaşın metinden ayrıldığı yahut da metinle yetinmeyerek zenginleştirdiği ikonografik yorumlarla sıklıkla karşılaşırız. Buna karşılık, herhangi bir yazılı metnin hikâyesinden yoksun murakka resimleri için bu tür bir metinsel bağlamdan söz etmek mümkün değildir.

İşte tam da burada, yukarıda değinilen görüntüyü çevreleyen sözlü ve/veya sözel bağlam tasviri okumak için daha da önemli hale gelir. Bu bağlamı çözümlemek üzere tasvirden hareket ettiğimizde, günümüzden bakıldığında resmi oluşturan "sıradan" öğeler gibi görünen bazı ikonografik detayların aslında Osmanlı resim dilinin -belki de daha geniş bağlamda İslâm resim sanatının- kendine özgü dinamiği içinde "belirli öykülere" tekabül eden imge kodlamaları yahut da kalıpları olduğunu varsaymak mümkündür. Bir başka söyleyişle, tasviri oluşturan ve benzeri olan pek çok örnekte, yine benzer bir şekilde kullanılan imge kalıpları belki de toplumun ortak hafızasında oluşmuş, üzerinde uzlaşılmış bazı anlamlar, hatta hikayeler, içeriyordu/taşıyordu. İşte bu önerme, bu yazı boyunca tartışılacak konuların da başlıca hareket noktasını oluşturacaktır.

Bu tür bir sorgulama için geniş bir coğrafya ve zaman dilimine yayılmış olan İslâm resim sanatına ve bu gelenek içinde başlı başına bir yer teşkil eden murakka resimlerine bütüncül olarak bakmak, kuşkusuz bu ve/veya bir yazının sınırlarını aşar. Bu sebeple de bu tartışmada, Osmanlı döneminde, çoğunlukla 17. yüzyılda,

1 Walter J. Ong, Sözlü ve Yazılı Kültür, Sözün Teknolojileşmesi, çev. Sema Postacıŏlu Banon, (İstanbul: Metis Yayınları, 2010), s. 19. 
kısmen de 18. yüzyılda yapılmış, genç erkek ve kadınların portrelerinin betimlendiği bir grup resim ele alınacaktır. Osmanlı tasvir sanatında 17. yüzyılla birlikte albüm resimlerinin üretiminde belirgin bir artış gözlenir. ${ }^{2} \mathrm{Bu}$ resimlerin çoğunluğunun saray dışında, "çarşı ressamları" olarak adlandırılan nakkaşlar tarafından yapılmış olduğu düşünülür. Bu gruba atfedilen eserlere bakıldığında saray örneklerine nazaran -hem üslup hem de ikonografi bakımından- daha "basit" bir anlatım dilinin benimsendiği söylenir. ${ }^{3}$ Bu saptama, "popüler kültürde" ya da daha az "tehlikeli” bir ifadeyle saray dışında üretilmiş resimlerdeki anlatım dilinin kodlarını çözümlemek için oldukça önemlidir. Nitekim bu basitlik eserlerin muhatap kitlelerini ve algılanma biçimlerini anlamak için ipuçları sunar. Bu ipuçlarını kavramak içinse, benzer bir tüketici kitlesine hitap eden sözlü/sözel kültür ve kültürel bellek üzerine yapılan çalışmalar yol gösterici olabilir.

Hafıza üzerine söylenenlere göre, bir imgenin toplumun ortak belleğinde ya da kolektif hafızada yaşayabilmesi için basitleştirilmesi ve üzerinde anlaşılan biçimlere dönüştürülmesi gerekiyordu. ${ }^{4}$ Bu sebeple de sözlü kültürde edebiyatın hafızada korunabilmesi için kolay hatırlanabilir olması önemli bir husustu. Bilginin yegane kaynağının hafıza olduğu modern öncesi toplumlarda, hatırlamanın önemi kuşkusuz hayatiydi. Peki nasıl hatırlıyorlardı, yani bilgi nasıl kalıcı olabiliyordu diye sorulduğunda; bu konuda çalışanların cevabı "kolay hatırlanabilecek şeyler düşünerek” şeklinde olmuştur. Bunun için de sözlü kültürde yüzyıllar boyunca yaşayan eserler incelendiğinde kullanılan dilin nesilden nesle bin bir güçlükle bir araya getirilmiş parçalanamaz bazı kalıplardan oluştuğu gözlenmiştir. Bu nedenledir ki, sözlü kültürde askerler hep kahraman, çınarlar hep ulu, prensesler de hep güzel olmuştur. Bu isimlere yeni sıfatlar eklenebilmiştir; ancak bir şartla, onların da üzerinde uzlaşılmış sıfatlar olması gereklidir. Sözlü gelenekle ilgili bir diğer ilgi çekici husus da, anlatımın özgünlügünün yeni öykü uydurmaya değil; anlatım süresince dinleyici ile kurulan etkileşimin niteliğine bağlı olmasıdır. Bu nedenle

2 Günsel Renda, "17. Yüzyıldan bir Grup Kıyafet Albümü,” 17. Yüzyıl Osmanl Kültür ve Sanatı Sempozyumu Bildirileri, 19-20 Mart 1998 (İstanbul, 1998), s. 153-178; Leslie Meral Schick, "Meraklı Avrupalılar İçin Bir Başvuru Kaynağı: Osmanlı Kıyafet Albümleri," Toplumsal Tarih 116 (August 2003), s. 4-9.

3 Metin And, “17. Yüzyıl Türk Çarşı Ressamları,” Tarih ve Toplum 6 (1985): 40-45; “17. Yüzyıl Türk Çarşı Ressamlarının Padişah Portreleri,” Türkiyemiz 58 (1989): 4-13.

4 James Fentress-Chris Wickham, Social Memory (Oxford: Blackwell Publishers, 1992), s. 47-48. Bu konuda ayrıntılı bilgi için ayrıca bkz. Jan Assman, Kültürel Bellek. Eski Yüksek Kültürlerde Yazı, Hatırlama ve Politik Kimlik, çev. Ayşe Tekin, İstanbul: Ayrıntı Yayınlar1, 2001. 
de sözlü kültür içinde her bir efsanenin çeşitlemeleri en az tekrarı kadar boldur. Her bir kahramanın zihinde yer etmesi için belirli bir "tip" olması gerekmiştir.

"Söz" ün toplumun belleğindeki yolculuğu üzerine yapılmış bu saptamalar, bu yazıda konu edilecek olan albüm resimleri söz konusu olduğunda oldukça aydınlatıcıdır. Zira bu tasvirlerin ya da imgelerin oluşumunda da benzer bir sürecin yaşanmış olması muhtemeldir. Daha açık bir ifadeyle, saray dışında gelişen ve olasılıkla da daha yaygın ve geniş bir kitleye sunulan albüm resimlerinde tıpkı sözlü ve sözel kültürde olduğu gibi belirli imge kalıpları oluşturulmuş olmalıdır. Böylece şimdiden baktığımızda, birbirini tekrar eden ve belirli "tipleri”" yineleyen portrelerin aslında ardındaki pek çok hikayeyi saklayan imge kalıpları olması ve özgünlüklerini tüketilme biçimleriyle kazanmaları hiç de şaşırtıcı olmayacaktır. Bir başka söyleyişle, bu tartışmada, günümüzden baktığımızda bazı genç erkek ve kadınların portreleri olarak gördüğümüz tasvirlerin, aslında belirli tipleri temsil eden bireyler oldukları, bu tiplerin de 17. yüzyılla birlikte belirginleşen toplumsal dokudaki değişim ve dönüşümlerin bir izdüşümü olduğu düşüncesi akla yakın görünmektedir ki; tüm bu tartışmalar, Osmanlı kültüründe "görsel okuma" kavramının gündeme gelmesi ve tartışılması için de bir vesile oluşturmaktadır.

Bu bağlamda, 17. yüzyıl Osmanlı tarihinin -yani bu tasvirlerin yoğunlaştığı dönemin- kendine özgü yeni dinamikleri resim sanatının oluşumu ve tüketiminde izlenen dönüşümleri/değişimleri manalı kılacak yenilikler sunar. Yazının ilerleyen bölümlerinde kısmen tartışılacak olan bu değişimler, İstanbul başta olmak üzere "şehirli" bir genç nüfusun kent hayatındaki rolünü öne çıkarmıştır. Çoğunlukla siyasal ve ekonomik gelişmelerin yol açtı̆̆ demografik değişimlerin sonucunda ortaya çıkan ve yoğunluklu olarak da bekar erkeklerden oluşan yeni bir sosyal/sosyolojik sınıf İstanbul'un kent kültürünü hem üretim hem de tüketim bağlamında etkilemiş görünmektedir. Bu yüzyılla birlikte yeni bir şehirli sınıfın belirginleşmesiyle, iletişim biçimleri de değişmiş; hamam, kahvehane gibi kadim mekanlar bu yeni iletişim biçimine uygun yeni roller üstlenmişlerdir. Bu değişimde sözlü ve yazılı kültürün de yeni sohbetlere hitap eden biçim ve içerik arayışlarına girdiği görülmektedir. ${ }^{6}$ Buna paralel olarak, 17 . yüzyılla birlikte farklı türde metinleri ihtiva eden karışık mecmuların çoğalması da yazılı biçimin aslında sözlü yolla edinilmiş edebiyatı yine sözlü yolla sürdürmenin bir aracı

5 Ong, Sözlü ve Yazılı Kültür, s. 29-96.

6 Cemal Kafadar, "Sohbete Çelebi, Çelebiye mecmûa...", Türk Edebiyatı Çalı̧̧maları VII, Mecmûa: Osmanlı Edebiyatının Kırkambarı, haz. H. Aynur, M. Çakır, H. Koncu, S. Kuru, A. E. Özyıldırım (İstanbul: Turkuaz, 2012), s. 46. 
olduğunu düşündürmektedir. Bu mecmualar, meclislerde paylaşılan şiirlerin -ya da belki hikayelerin- derlendiği hatırlatma defterleri gibi kullanılmıştır. ${ }^{7}$ Benzer derlemeler içinde saklanan tasvirler de bir tıpkı şiir kıtaları ya da hikaye parçaları gibi hatırlatma; ama aynı zamanda da "anlatma" aracı olmalıydı. 17. yüzyıldan itibaren Osmanlı tasvir sanatında artan bu tür mecmualarda karşımıza çıkan erkekler ve kadınlar -kuşkusuz bu imgeler çoğaltılabilir- örtük ya da açık pek çok hikayenin de hem taşıyıcısı hem de anlatıcısıydı.

\section{Şehrin Oğlanları ve Maceraları}

16. yüzyıl sonundan itibaren Osmanlı tasvir geleneğinde yaygınlık kazanan albüm resimleri, sadece resim sanatının yolculuğunda önemli bir biçim ve içerik değişikliğine değil, aynı zamanda erken-modern dönem Osmanlı sosyal tarihinin önemli bir kırılma noktasına da işaret eder. Nitekim bazıları saray için hazırlansa da "şehirdeki" hayatın izdüşümlerinin canlı bir şekilde yansıdığı bu albümlerde sıklıkla karşımıza çıkan genç erkek tasvirleri bir resim temasının ötesinde, 17. yüzyılla birlikte Osmanlı sosyal tarihine damgasını vuran bir sosyal sınıfın da yansımalarıdır.

Genel olarak 17. yüzyılın başından itibaren yaygınlaşan albüm resimlerinde "stereotip" diyebileceğimiz bir "gençlik" temsili ile karşılaşırız. Bu grubun fiziksel açıdan en belirgin özelliklerinden biri sakalsı olmalarıdır. Sakalsız olma, ileride değinileceği gibi, insanın yaşam çevrimindeki biyolojik bir durumun ötesinde, Osmanlı toplumunda belirli bir sosyal sınıfın tanımlayıcısı olarak da görülmüştür. $\mathrm{Bu}$ nedenle de tasvirlerde sakalsız olma sadece fiziksel bir özellik değil, aynı zamanda sosyal kategoriye de işaret ediyor olmalıdır. Bunun dışında genellikle ince, uzun ve "güzel" yüzlü olan bu gençlerin portrelerini, ellerinde tuttukları kitap, çiçek ya da bellerinde taşıdıkları hançer ya da kama gibi nesneler tamamlamıştır. Bazen tek başlarına, bazen albüm içinde karşılarına yerleştirilmiş genç bir kadınla betimlenen bu gençler, bazen de bir meclis içinde karşımıza çıkarlar.

Bu farklı ikonografik yorumların en bol ve zengin örneklerine Sultan I. Ahmed (sal. 1603-1617) için Kalender Paşa (ö. 1616) tarafından hazırlanmış olan bir albümde rastlarız. Sultanın ismi ile, yani I. Ahmed Albümü olarak anılan, içinde hat, resim ve çizimlerin bulunduğu mecmuada bahsi geçen gençler çeşitli

7 Snjezana Buzov, "Osmanlıda karışık içerikli mecmûalar: bir başka arşiv," Türk Edebiyatı Çalışmaları VII, Mecmûa: Osmanlı Edebiyatının Kırkambarı, haz. H. Aynur, M. Çakır, H. Koncu, S. Kuru, A. E. Özyıldırım (İstanbul: Turkuaz, 2012), s. 38. 
biçimlerde betimlenmişlerdir. ${ }^{8} \mathrm{Bu}$ tasvirlerin pek çoğunda gençlerin ellerinde kitapla, ya da kitap okurken gösterildiği dikkati çeker. Mesela, albümde yer alan resimlerden birinde, sakalsız bir genç ağaç altında, doğa içinde tasvir edilmiştir (Resim 1). ${ }^{9}$ Kırmızı pantolonu, düğmeleri göğsüne kadar açılmış üst giysisi, belindeki kuşağına sıkıştırılmış hançeri ve omzuna bağladığı pelerine benzer kaftanı ile aynı albümde ve yaklaşık aynı dönemlerde yapılmış başka albümlerde görülen genç betimlemelerinin bir benzeridir. Hem fiziksel görünümü ve vücut dili hem de taşıdığı nesneler -elindeki cönke benzer kitabı ve belindeki hançeri- belli ki portresinin oluşumunda belirleyici olan ikonografik detaylardır.

Aynı albümde yer alan bir diğer örnekte ise bu defa benzer gençlere bir meclis içinde rastlarız. Burada, yine sakalsız ve iyi giyimli bir genç bir ağacın altına serilmiş halıda, sırmalı yastığına dayanarak oturmaktadır (Resim 2) ${ }^{10}$ Bir eliyle önündeki hizmetkârın sunduğu içeceği alırken, diğeriyle açık bir kitabı tutmaktadır. Karşısında ise kendisiyle yaklaşık aynı yaşlarda ve yine sakalsız olmakla birlikte daha mütevazı bir görünüme sahip iki genç oturmaktadır. Yerdeki halı, yastık gibi detaylar ve üzerindeki kıyafeti, bu gencin sosyal statü bakımından meclisin en itibarlısı olduğunu düşündürür. Özellikle de, gerideki tepenin ardında boş bir zemin üzerinde karşılıklı oturan iki derviş figürüyle karşılaştırıldığında, ön düzlemdeki sahnenin şaşaası daha bir belirginleşir. Gerideki dervişler, bir yandan ellerindeki kulpsuz fincanlardaki içeceklerini -belki kahve- keyifle içerken, diğer yandan da birinin elinde tuttuğu kitabı tartışıor olmalıydılar. Belli ki farklı sosyal ve mesleki sınıfa ait bu grupları hem birleştiren hem de ayıran bu tasvir, ilginç ikonografisiyle sosyal dokudaki ayrışmalar ya da birlikteliklere de sşık tutmaktadır.

Bu tür örnekleri, hem aynı albüm içinde yer alan başka resimlerle hem de benzeri eserler içindeki tasvirlerle çoğaltmak mümkündür. Tasvir edilme biçimlerinden ve de taşıdıkları nesnelerden şehrin nimetlerine ya da sunduğu olanaklara -sosyalleşme biçimleri vs.- düşkün oldukları anlaşılan bu figürler, hem fiziksel görünümleri hem de yaşam biçimleri ile 16. yüzyılın ikinci yarısından itibaren Osmanlı yazılı kaynaklarında belirgin bir şekilde izlerini takip etmeye başladığımız "şehr oğlanları" ile pek çok benzerlik taşırlar.

8 TSMK, B. 408. Albüm hakkında bkz. Emine Fetvacı, "The Album of Ahmed I," Ars Orientalis, 42 (2012):127-138. Serpil Bağc1, "Presenting Vassal Kalender’s Works: The Prefaces of Three Ottoman Albums,” Muqarnas, 30 (2013), s. 255-313.

9 TSMK, B. 408, v. 16a.

10 TSMK, B. 408, v. 17a. 
TÜLÜN DEĞİRMENCİ
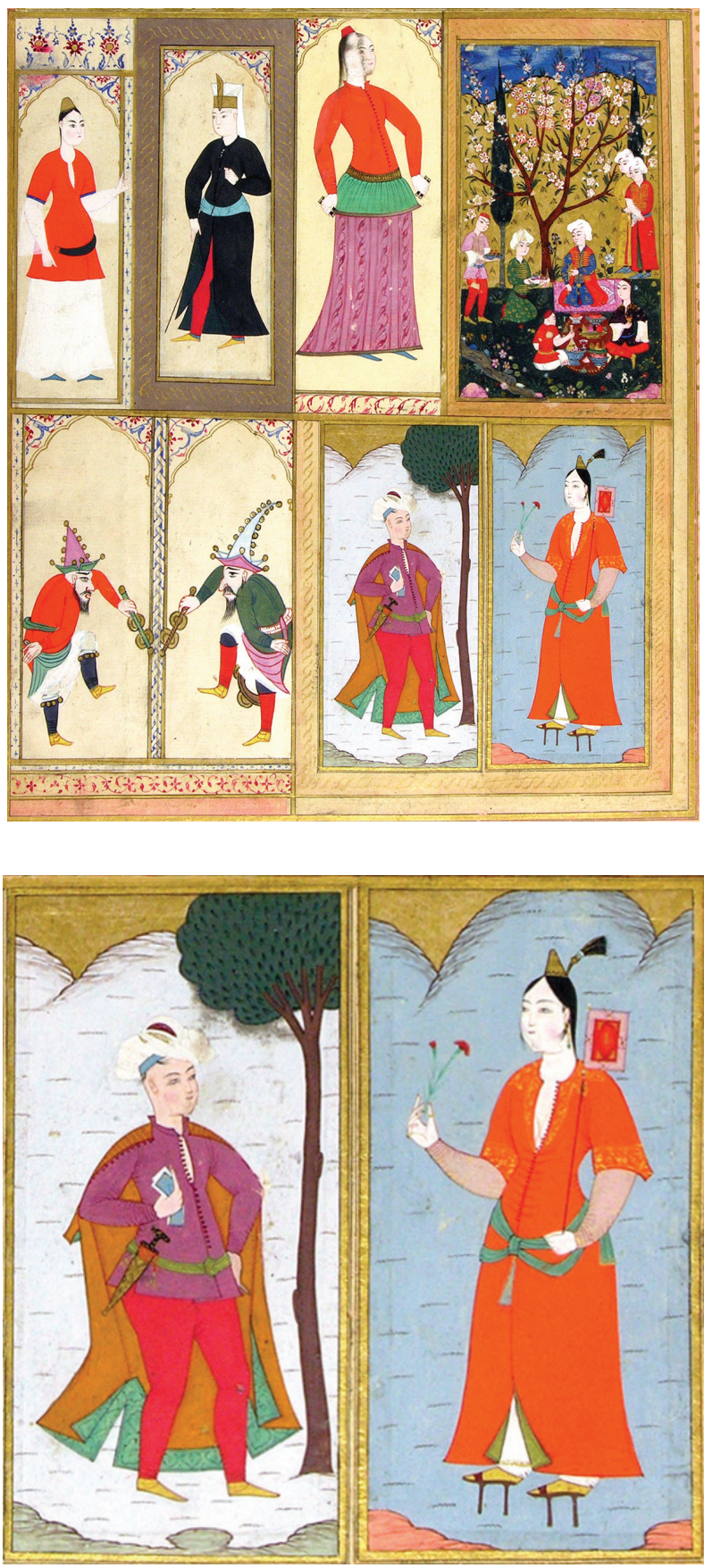

Resim 1. I. Ahmed Albümü, TSMK, B. 408, v. 16a (Bağc1 2013). 
OSMANLI TASVİR SANATINDA GÖRSELIN "OKUNMASI"

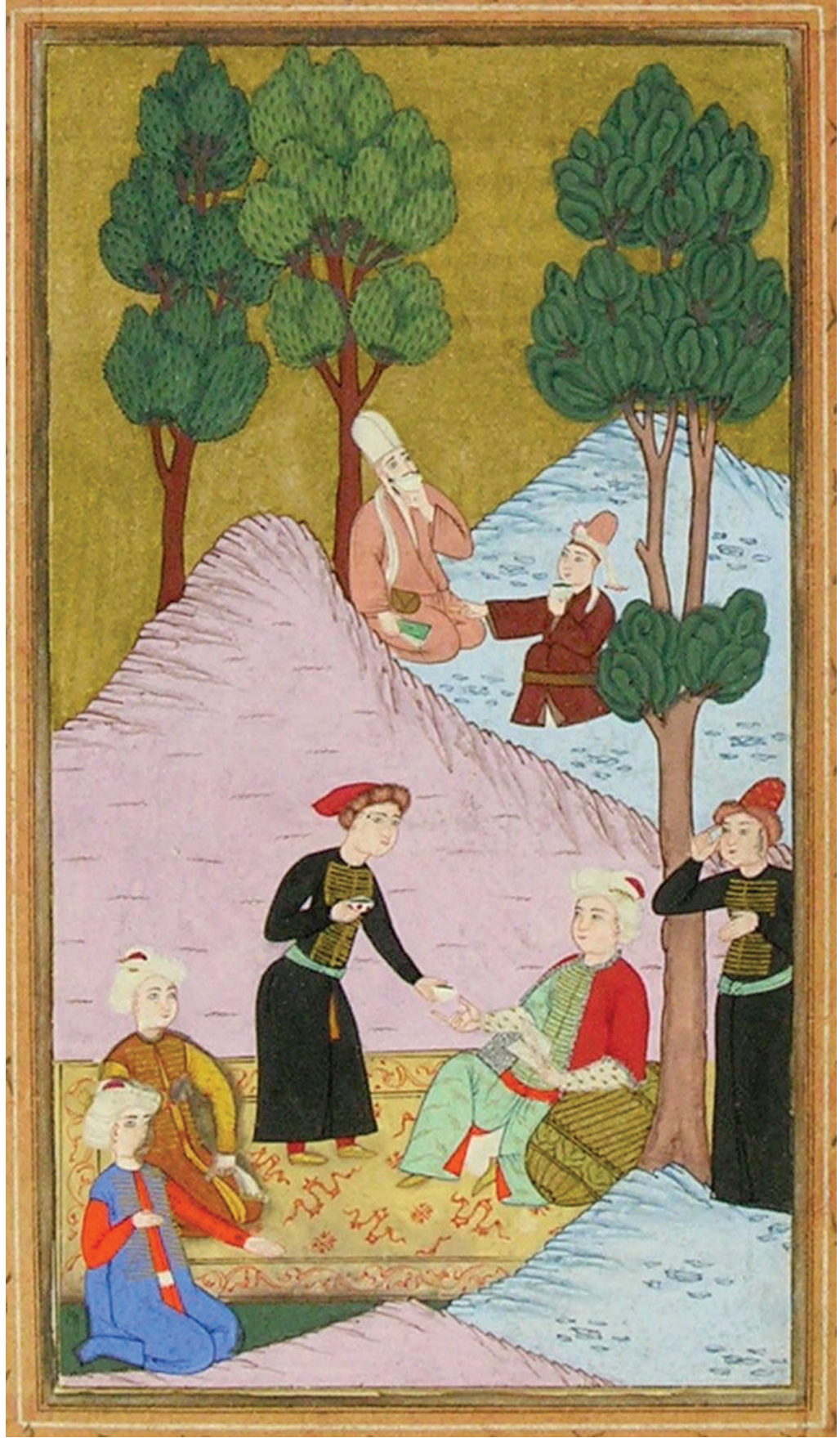

Resim 2. I. Ahmed Albümü, TSMK, B. 408, v. 17a. 
Görünüşleri ve hayat tarzlarıyla Osmanlı şehirlerinin ayırt edici gruplarından biri olduğu anlaşılan şehir oğlanları hakkında en tafsilatlı bilgiyi Gelibolulu Mustafa 'Alî (1541-1600) verir. Mevấidü’n-nefâis fì Kavấidi'i-mecâlis adlı eserinde pek çok kez şehir oğlanlarından bahseden 'Alî’nin anlattıklarından ilginç bir portre karşımıza çıkar. 'Alî̀ye göre, yalan söyleyenler genellikle şehir oğlanları arasından çıkar. İçoğlanlarının seçimi konusunda dikkat edilmesi gerekenleri anlatırken ise "gizli hazineleri engerek yılanlarına nasib olmuş, ince belli güzelleri" yani şehir oğlanı kısmından olup levend ve çapkınlara karışmış, meyhanelere girip çıkmış ve herkesçe tanınmış şehir oğlanlarının katiyetle alınmaması gerektiğini söyler. Yine "sâde-rû" adlı henüz sakalı çıkmamış güzel oğlanlardan bahsederken de, bu oğlanları bekleyen tehlikelerden birinin ise henüz sâde-rû iken kovulan şehir oğlanlarının tuzağına düşmeleri olduğunu nakleder. ${ }^{11}$ Bu ifadelere genel olarak bakıldığında, şehir oğlanı ve sâde-rû olarak tanımlanan gençlerin cinsel çekim objesi olarak toplum için tehlike yarattığı düşünülen bir grup olarak kontrol altına alınmaya çalışıldığı izlenimi ortaya çıkar.

Nitekim, bu gençlerin Osmanlı hukuk sistemi içinde de korunduğunu gösteren fetvalar mevcuttur. Bu fetvalarda "oğlan" olarak tanımlanan sakalı çıkmamış genç erkeklerin müşteha (iştah uyandıran) kabul edilerek koruma altına alındığı görülür. ${ }^{12}$ Kanuni Sultan Süleyman'ın (sal. 1520-1566) ünlü şeyhülislâmı Ebussuud Efendi'ye (ö. 1574) kahve hakkında sorulan sorulardan birindeki ifadeler de bu bağlamda dikkat çekicidir. Soruda, başıbozuk tayfasından bazı kimselerin geçimlerini sağlamak için kahvehaneler tutup hengamelerinin "germ" olması için yanlarına yalın yüzlü şakirtler alıp tavla ve satranç gibi oyunlara dalarak namaz vakitlerini kaçırmalarından bahsedilmektedir. ${ }^{13} \mathrm{Bu}$ ifadeler yalın yüzlü olarak tarif edilen sakalsız gençlerin sosyal hayattaki algıları hakkında epeyce aydınlatıcıdır.

17. yüzyılda Nevizâde Atayînnin (1583-1635) mesnevilerinde de pek çok hikayenin kahramanı olarak benzer genç tasvirleriyle karşılaşırız. Atayî, bir yandan kadınlara ilgi duymanın beraberinde şehveti getireceğini belirterek asıl sevginin civanlara duyulan sevgi olduğunu söylerken, diğer yandan da bu sevginin cinsel

11 Gelibolulu Mustafa 'Âlî, Mevâ idiü’n-nefäis fî-Kavâ idi'l-mecalis, ed. Mehmet Şeker (Ankara: Türk Tarih Kurumu Yayınları, 1997), s. 125, 155, 164, 182, 195, 208.

12 Leslie Peirce, "Ekberiyet, Cinsellik ve Toplum Düzeni: Modern Dönemin Başlang1cında Toplumsal Cinsiyetle İlgili Osmanlı Söz Dağarcığı,” Modernleşmenin Eşiğinde Osmanlı Kadınları, ed. Madeline C. Zilfi, çev. Necmiye Alpay (İstanbul: Tarih Vakfı Yurt Yayınları, 2009), s. 174-175.

13 M. Ertuğrul Düzdağ, Şeyhülislam Ebussuûd Efendi Fetvaları Işı̆̆ında 16. Asır Türk Hayatı (İstanbul: Enderun Kitabevi, 1983), s. 148-149. 
isteklerden uzak olmasını şart koşar. Belli ki bunun güçlüğünün de farkında olan Atayî, anlatımın devamında yılda yalnız bir kere el öpmeye izin verirken şehvete ve nefse karşı uyarısını da tekrar eder. ${ }^{14}$ Yazarın benzer ifadelerine mesnevilerinde pek çok kez rastlanır. Mesela bir yerde, yetişme çağındaki oğlanlara meyli olanları uyarır, bunları baştan çıkarmanın kötülüklerini anlatır. ${ }^{15}$ Bazı hikayelerinde de genç erkeklere musallat olan adamların başlarına gelen küçük düşürücü olaylar, belli ki ibret olsun diye anlatılır. ${ }^{16}$

Toplum için yarattıkları "tehlikeye” rağmen Osmanlı yazarlarının şehir oğlanlarına olan yaklaşımları tamamen negatif de değildir. Mesela, Gelibolulu Mustafa 'Alî bir yandan şehir oğlanlarının "uygunsuz" tavırlarını eleştirirken diğer taraftan da edebiyat meclislerindeki yeteneklerini methederek haklarını teslim eder. Konuşma kuralları ve adab-1 muaşeretten söz ettiği bölümde, sohbeti dinlenebilecek kişiler arasında sanatlı sözlerden anlayan şehir oğlanlarını da sayar. Alışveriş konusundan bahsederken ise, şehir oğlanlarının toplum içindeki konumları hakkında önemli bir ip ucu sunar. "Huyunda cimrilik olan alışverişe yeni başlamış şehir oğlanları” ömürleri boyunca alışveriş yapma mutluluğunu az görürler ve pazarllğa çok düşkünlerdir der. ${ }^{17}$

Yukarıda değinilen Osmanlı yazarlarının çizdiği tabloya bakıldığında, şehrin sunduğu olanakları kullanan ve bundan dolayı da eleştiri ve kuşku ile karşılanan şehirli bir grup ile karşılaşırız. Bu kitlenin şehirdeki "güruh" olarak tanımlanan diğer gruplarla bağlantısı olan, ümmi gruplarla yarı-eğitimli diyebileceğimiz "orta sınıf” arasında yer alan özgün bir kitle olduğu söylenir. ${ }^{18}$ Yine 17. ve 18. yüzyıl Osmanlı kroniklerinden ve farklı türdeki metinlerden elde edilen izlenimle, şehir oğlanı tanımlamasının 17. yüzyıl ortalarından itibaren ayrı bir sosyal grup yerine bir karakter türünü tanımlamaya başladığı belirtilir. ${ }^{19}$

Görülüyor ki, 17. yüzyıldan itibaren, bu tanımlama şehirle ve şehir hayatı ile ilişkisi olan gençler için kullanılmış olmalıdır. Bu konudaki en çarpıcı hikâye ise günümüze 18. yüzyıl başında istinsah edilmiş bir kopyası ile ulaşan, ancak

14 Tunca Kortantamer, Nev î̀-zâde Atâyî ve Hamse’si (İzmir: Ege Üniversitesi Yayınları, 1997), s. 234.

15 A.g.e. s. 207-208.

16 A.g.e. s. $193-194$.

17 Gelibolulu Mustafa 'Âlî, Mevấidünn-nefäis, s. 229.

18 Marinos Sariyannis, "Mobs, Scamps and Rebels in Seventeenth-Century İstanbul," International Journal of Turkish Studies, 11/1-2 (2005), s. 4-5.

19 Sariyannis, yukarıda zikredilen makalesinde şehir oğlanları ile ilgili kroniklerde anlatılan anekdotlara geniş olarak yer verdiği için burada tekrar edilmemiştir. 
17. yüzyıl başında oluştuğu muhtemel olan bir hikâye kitabında yer alır. ${ }^{20} \mathrm{Bu}$ hikâyede, 17. yüzyıl başında yaşayan Kastamonulu Sipahi Ali üç aylık ulufesini saraydan almak üzere İstanbul'a geldiğinde Sultan Ahmed civarında eski bir dostu ile karşılaşır. Birlikte geceyi geçirmek üzere dostunun evine giderlerken bir kahvehanenin önündeki kalabalık Ali’nin dikkatini çeker ve bu kalabalığın nedenini arkadaşına sorduğunda arkadaşı anlatmaya başlar. Bu kalabalığın sebebi kahvehanede kıssahanlık yapan Çavuş-zâde'dir. Şahtan dervişe kadar herkes bu kıssahana tutulmuştur der ve bu belaya yakalanmamak için kahvehaneye girmemesi konusunda Ali'yi uyarır. Bu uyarı üzerine Ali'nin verdiği cevap oldukça ilginçtir. Ali Bey arkadaşına, "Siz şehir oğlanısınız, işiniz sevmek ve sevilmek, oysa biz Türk adlıyız, bizim aşktan haberimiz yoktur. Dünyadaki sevgimiz iyi atlara ve güzel halılara karşıdır” diyerek, 17. yüzyıl Osmanlılarının zihniyet dünyasındaki ayrımlar hakkında ilginç bir ip ucu sunar. ${ }^{21}$ Ali Bey’in sözleri şehir oğlanı olarak tanımlanan kişilerin, "taşradaki" hayatın zor koşullarından bihaber, şehrin nimetlerine dalarak aşk-meşk peşinde koşan, biraz da bu yüzden eleştirilen şehirlileri tanımladığını düşündürür. Aslında, bu kabullerle çağdaş olan bir albüm resmi de bu sözleri sanki surete dönüştürür.

İsveç Elçisi Rålamb için 17. yüzyıl ortalarında hazırlanan bir kıyafet albümünde yer alan tasvirlerden birinde sakalsız, genç bir erkek omzuna bağladığ 1 kenarı kürklü kaftanının püskülünü sallayarak pür neşe içinde yürürken betimlenir (Resim 3). ${ }^{22}$ Söz konusu tasvirde, figürün altında herhangi bir meslek ve kişi ismi veyahut da etnik kimlik belirtilmez; sadece "İstanbullu" olarak tanımlanır. 18. yüzyıldan gelen bir hikaye kitabındaki ayrıntı ise, İstanbullu olmanın ayırt edici bir "kıyafetinin" olduğunu düşündürür. 1731-32 yılında istinsah edilmiş bir kopyası ile bilinen Mısır Valisi Koca Cafer Paşa’nın Hikayesinnde Halil ve Süleyman adlı iki mirasyedi gencin İstanbul'dan ayrılarak Mısır'a gitmeleri ve burada başlarından geçen maceralar anlatılır. Cafer Paşa bu iki güzel oğlanla Mısır'da bir kahvehanede karşılaşır ve henüz tanışmadığı bu gençlere uzaktan bakarken aklından şunları geçirir: "bunlar Mısır uşağına benzemez, İstanbullu olmaları gerek." 23

20 Hikâyât-ı Sipâhî-yi Kastomonî ve Tûtî, Millet Kütüphanesi, Ali Emiri, Roman 146.

21 Hikâyât-ı Sipâhî-yi Kastomonî ve Tûtî, Millet Kütüphanesi, Ali Emiri, Roman 146, v. 7a.

22 Tadeusz Majda, "Rålamb'ın Türk kıyafetleri Albümü," Alay-ı Hümayun, İsveç Elçisi Rålamb’n İstanbul Ziyareti ve Resimleri, 1657-1658, ed. Karin Ådahl, çev. Ali Özdamar (İstanbul: Kitap Yayınevi, 2006), s. 223.

23 Misır Vâlisi Koca Cafer Paşảnın Hikâyesi, Süleymaniye Kütüphanesi, Hacı Mahmud Efendi No. 6264, v. 3 b. 


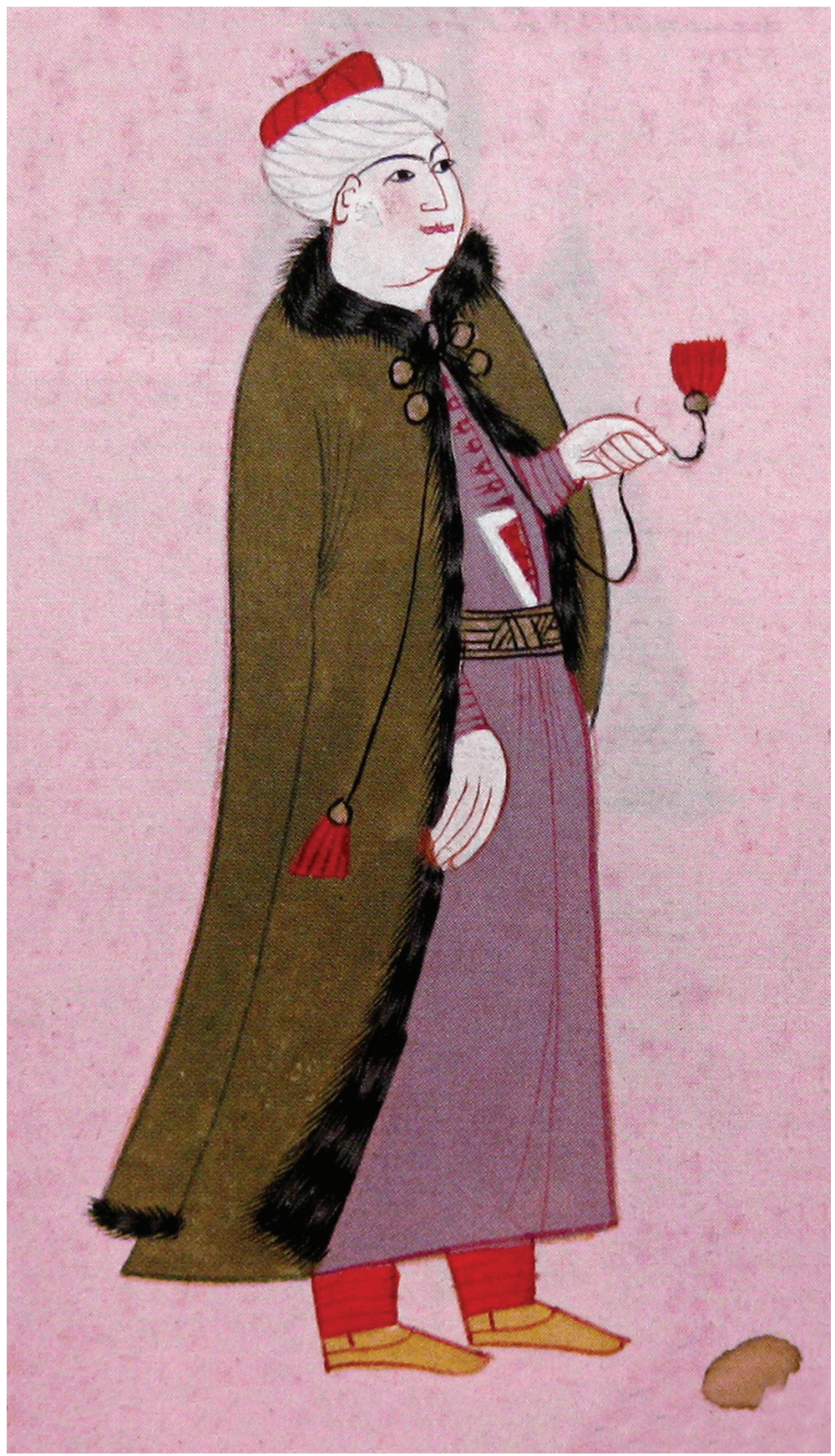

Resim 3. Rålambin Kryafet Albümü, Stockholm Ulusal Kütüphanesi, Cod. Rål. 8:0 no. 10 (Majda 2006) 
Peki nasıl olur İstanbullu? Tekrar söz konusu albüm resmine dönersek, tasvirdeki figürün en dikkat çekici fiziksel özelliği kuşkusuz henüz sakalsız, yani genç, olmasıdır. Omzuna bağladığı kaftanının püskülünü bir eliyle sallaması ise, tasvirdeki kişinin neşeli ve biraz da "umursamaz" tavrının bir aksidir adeta. Kuşağındaki kırmızı deri ciltli kitabı/mecmuasıysa, tüm bu "hercai” tavrına karşın bu gencin kitapların dünyası ile olan ilişkisinin bir göstergesi; İstanbullu olmanın da bir yansıması olmalıdır. Tıpkı Gelibolulu Mustafa 'Alînnin bahsettiği şehir oğlanları gibi.

16. yüzyıl sonunda Gelibolulu Mustafa 'Alî’nin "gizli hazineleri engerek y1lanlarına nasip olmuş" diyerek tanımladığı; 17. yüzyılda Nevizâde Atayînin sadece el öpmeye izin verdiği ya da Kastamonulu Sipahi Ali'nin aşk-meşk peşinde koşmakla eleştirdiği bu şehirli genç tipi daha sonraları "İstanbul hikayeleri” ya da "Tıflî Hikayeleri” olarak adlandırılacak hikaye grubundaki genç, güzel ve çapkın şehirli oğlanlarla da büyük bir benzerlik taşırlar. İstanbul hikâyelerinin bu genç kahramanları "gerçek hayattan" ilham alınarak yaratılmış -belki de yaşamış-, isimleri belli kişilerdir. Çoğunlukla tüccar çocuklarıdır ve babalarının ölümü üzerine miraslarını etraflarına toplaşan "kötü" dostlarla ya da "geçkin" kadınların "aşk tuzaklarında" tüketirler. Bu sırada da başlarından sayısız macera geçer ki bunlar da hikâyelerin konusunu oluşturur. Hemen hepsi IV. Murad devrinde (1623-1640) geçen bu hikayelerde Tiflî de çoğunlukla hikayenin kahramanı ve de anlatıcısı olarak karşımıza çıkar. Tıflî Hikayeleri olarak adlandırılmalarının sebebi de bundandır. ${ }^{24}$ Anlaşılan o ki, İstanbul'un gündelik şehir hayatından ilham alınarak yaratılan bu "tipler" ve onların İstanbul'un gerçek sokak ve mekanlarında geçen macera dolu öyküleri daha çok sözel bir dünyada yaşayarak kentlilerin belleğinde güçlü bir şekilde var olmuşlardır.

Bu hikayelerden birinde, öykünün ana kahramanı olan Tayyarzâde adlı gencin tarifi, bu kahramanların şehir oğlanları ile olan olası bağlantısını güçlendirir. Hikâyede Tayyarzâde şöyle anlatılır: "Yaşı on sekiz yirmi yaşında olup gayet nefesi güzel, nazik ve zarif, iyi Farisi bilir, Arabi dahi anlar, güzel sedası var, musiki-şinâs, gayet mi mahbup, güzel santur çalar ve güzel oyma yazı ve şükûflar oyar ve güzel tasvir ve bazı resimler bilir. Bir nazik, taze mahbuptur..."25 Tiflî Hikâyesi olarak maruf bir başka hikâyede de, meclislerde ehl-i keyf'e hizmet eden kimsenin vasıfları şöyle tarif edilir: "ziyade mahbup ve ziyadesiyle şivekâr ve lisan-fasih, tûtî-zebân

24 Pertev Naili Boratav, Halk Hikâyeleri ve Halk Hikâyeciliği (İstanbul: Adam Yayınları, 1988), 2. ed., s. 99-100; Hasan Kavruk, Eski Türk Edebiyatında Mensûr Hikâyeler (İstanbul: Milli Eğitim Bakanlığı Yayınları, 1998), s. 75-76.

25 David Selim Sayers, Tiflî Hikâyeleri (İstanbul: Bilgi Üniversitesi Yayınları, 2013), s. 208. 
ola ve pak ola, işaretle fehmeyleye, bunun gibi âdeme ehlikeyif âdem muhtaçtır." 26 Burada tarif edilen gençlerin hem fiziksel özellikleri hem de yetenekleri 16. yüzyıl sonunda bahsi geçen şehir oğlanları ile neredeyse aynıdır. Albümlerde karşımıza çıkan genç betimlemeleri de adeta bu çapkınların portreleri gibidir. ${ }^{27}$ Zaten hikâyelerde, bu genç ve güzel oğlanların "mahbup-dost", "hub-perest" gibi adlarla anılan erkeklerle ve yine isimleri ile anılan genç ve güzel cariyelerle olan maceraları anlatılır. Peki, bu tabloda hikayelerin diğer kahramanları, güzel cariyeler nerededir?

\section{Hikâyelerin Diğer Aktörleri: Cariyeler}

Yukarıda değinilen genç tasvirlerinin bazılarının albüm içindeki yerleştirilme biçimlerine bakıldığında ilginç bir detay dikkati çeker. Pek çok örnekte, bu gençlerin karşısına genç kadınlar yerleştirilmiştir (Resim 1). ${ }^{28} \mathrm{Bu}$ kadınların yönleri genç erkeklere doğrudur. Bazı örneklerde sanki tasvirdeki genç erkek elindeki kitabı karşısındaki kadına okumaktadır, yahut da tuttuğu çiçeği ona uzatmaktadır. Bu tür düzenlemelerin sıklıkla tekrarlandığı I. Ahmed Albümü’nün önsözünde, Kalender Paşa resimleri bir araya getirirken birbirine uygunluğuna göre düzenlediğini söylemesi ${ }^{29}$ ise tasvirlerdeki bu "karşılaşmanın” bir tesadüfün değil bilinçli bir tasarımın neticesi olabileceğini akla getirir.

$\mathrm{Bu}$ tür genç erkek ve kadınların albüm içinde karşılıklı yerleştirilmelerine sadece I. Ahmed Albümü’nde değil başka örneklerde de rastlamak mümkündür. Mesela, yaklaşık aynı dönemde, 16. yüzyıl sonu 17. yüzyıl başında yapıldığı düşünülen ve hem konu hem de üslup bakımından I. Ahmed Albümü'ne benzeyen bir albümde de benzer bir şekilde genç bir erkek ve kadının karşılıklı olarak sayfa üzerine yerleştirildiği görülür. Buradaki düzenlemede erkek figür elindeki çiçeği karşısında duran kadına uzatmaktadır ve üstelik bu sefer her iki genç de tıpa tıp aynı doğa içinde gösterilmişlerdir (Resim 4). ${ }^{30}$

26 Sayers, Tiflî Hikâyeleri, s. 180.

27 Aynı albümlerde yer alan "Acem” ya da "Derviş” tiplemeleri de, tıpkı İstanbullu oğlanlar gibi, belli ki hikayelerde çıkan kahramanlardı. Bu konuda örnekler için bkz. Tülün Değirmenci, "An Illustrated Mecmua: The Commoners Voice and the Iconography of the Court in Seventeenth-Century Ottoman Painting," Ars Orientalis, 41 (December 2011), s. 186-218.

$28 \mathrm{Bu}$ tür yerleştirmeler için aynı albümde şu resimlere bakılabilir: TSMK, B. 408, v. 9a, $14 \mathrm{~b}, 25 \mathrm{a}, 27 \mathrm{a}$.

29 Bağcl, a.g.e. s. 304.

30 Albüm, Dublin, Chester Beatty Library, T. 439, v. la. Katalog bilgisi için bkz. V. Minorsky, The Chester Beatty Library, A Catalogue of the Turkish Manuscripts and Miniatures, (Dublin: Hodges Figgis \& Co. Ltd, 1958), s. 68-71. 
TÜLÜN DEĞİRMENCİ

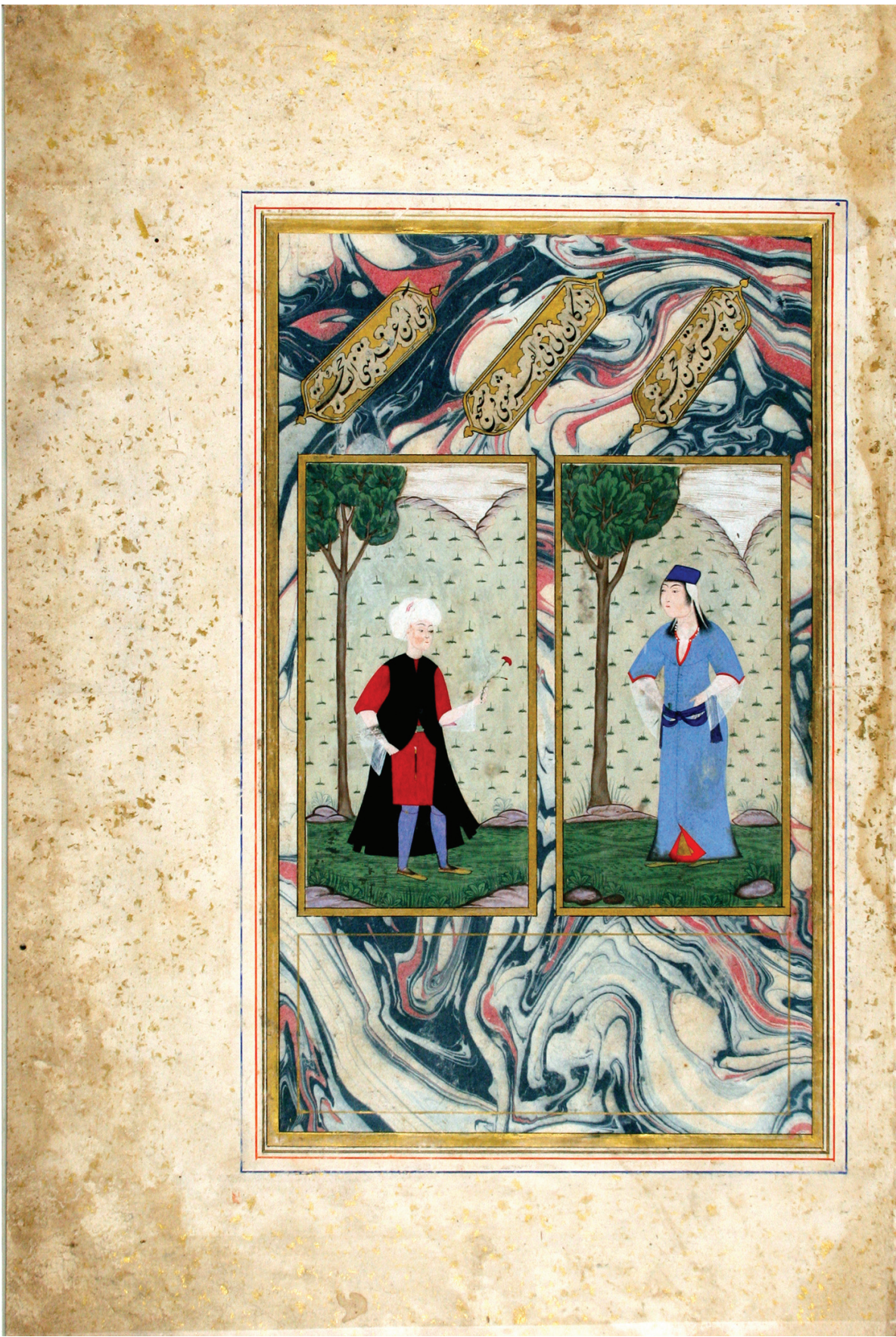

Resim 4. Albüm, Dublin, Chester Beatty Library, T. 439, v. 1a. 
Bu tasvirlere bakıldığında tıpkı yukarıda değinilen "gençlik temsili” gibi bu kadın tasvirlerinde de yinelenen bir "stereotipten" bahsetmek mümkündür. Çoğunlukla boş bir zemin üzerinde ya da bir doğa içinde ayakta tasvir edilen bu kadınların üzerlerinde genellikle göğsü dekolteli uzun giysiler -çoğu kez kırmızı renklidir elbiseleri- ve başlarında sivri hotozlar vardır. Ellerinde yelpaze, çiçek, meyve, kitap, içki şişesi ve kadeh gibi nesneler tutarlar. Görüldüğü üzere bu tür bir kıyafet ve ellerindeki nesneler kamusal alan için pek uygun değildir. Zaten bazı resimlerde tasvirin köşelerindeki kemer betimlemeleri, söz konusu kadının bir mekan içinde betimlendiğini gösterir. Peki doğa içinde olanlar için durum nedir? Bu tür kıyafetlerle sokağa mı çıkıyorlardı? Kamusal mekan tartışmalarında, sivil ve dinî otoritenin dahil olamadığı duygusal ve fiziksel alan, mekan olarak tanımlanır. Yani kamusal alanda da bazı özel alanlar oluşabildiği gibi, özel alanlarda mahremiyetin ihlali de söz konusu olabilir. ${ }^{31} \mathrm{Bu}$ tanımlama doğa içinde gösterilen bu kadınların aslında tek başlarına ya da karşılarına yerleştirilmiş olan gençlerle, fiziksel bir "mekanın" varlığına ihtiyaç duymadan mahrem bir alan yaratabildiklerini düşündürür.

Bir diğer 17. yüzyıl albümü içinde yer alan kadın portreleri ise, tasvirlerdeki ortaya çıan bu genç kadın imgesi üzerine olan meraklarımızı bir nebze de olsa aydınlatır. 17. yüzyılın ilk yarısında hazırlandığı düşünülen bu albümde divan şairlerine ait kıtalar ve farklı tipte kişilerin portreleri yer alır. ${ }^{32} \mathrm{Bu}$ portrelerin bazılarında, yine bir doğa içinde tasvir edilmiş genç kadınlar betimlenir. Üzerlerinde uzun giysileri, başlarında yine hotozlu başlıkları olan bu kadınlar ellerinde yelpaze, çiçek ve küçük birer meyve tutarken gösterilmişlerdir. Diğer örneklerden farklı olarak bu defa kadınların üzerlerine isimleri not edilmiştir. Bu notlara göre kadınlardan birinin adı Saçlı Raziye (Resim 5), diğerinin adı Elleri Güzel (Resim 6), bir diğerinin adı da Şems u Kamer'dir.

Peki kimdir bu kadınlar? Osmanlı toplumu gibi kadının kamusal alanda her türlü görünürlüğünün katı kurallarla yasaklandığı, özellikle de şehirli kadınların bazı nadir olaylar dışında çoğunlukla evle sınırlanan bir hayat yaşadığı bir toplumda ${ }^{33}$ tasvirlerde boy gösteren bu kadınlar da nereden çıkmıştır? Son olarak

31 Tülay Artan, "Forms and Forums of Expression: İstanbul and Beyond, 1600-1800," The Ottoman World, ed. Christine Woodhead, (New York: Routledge, 2012), p. 380.

32 Albüm, Londra British Library, Or. 2709. Norah M. Titley, Miniatures from Turkish Manuscripts, A Catalogue and Subject Index of Paintings in the British Library and British Museum (London: The British Library, 1981), pp. 1-2.

33 Cemal Kafadar, "Women in Seljuk and Ottoman Society up to the mid-19th Century," Woman in Anatolia: 900 Years of the Anatolian Woman (İstanbul: Turkish Republic Ministry of Culture,1993), pp. 200-203. 
TÜLÜN DEĞİRMENCİ

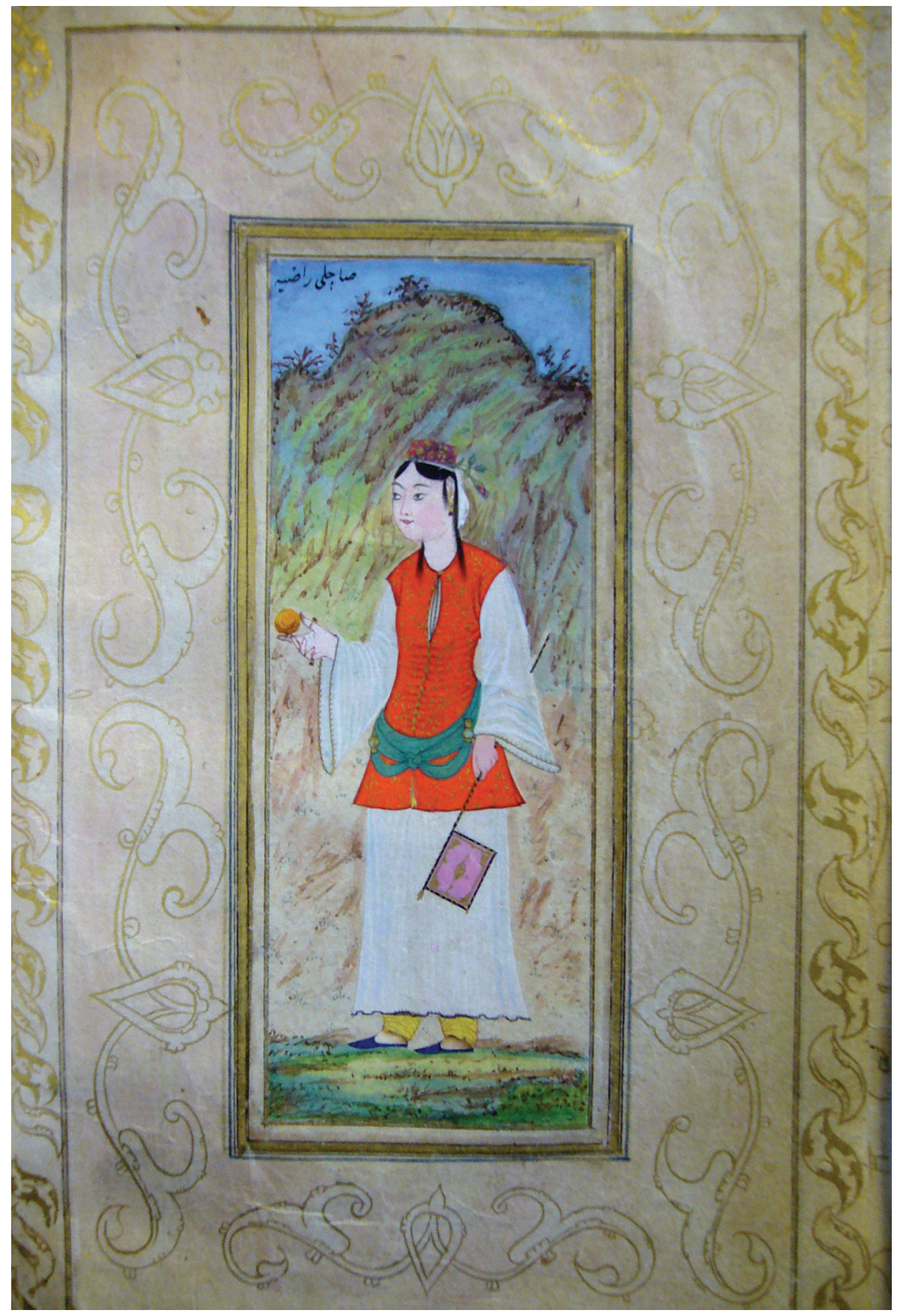

Resim 5. Albüm, Londra British Library, Or. 2709, v. 7b. 


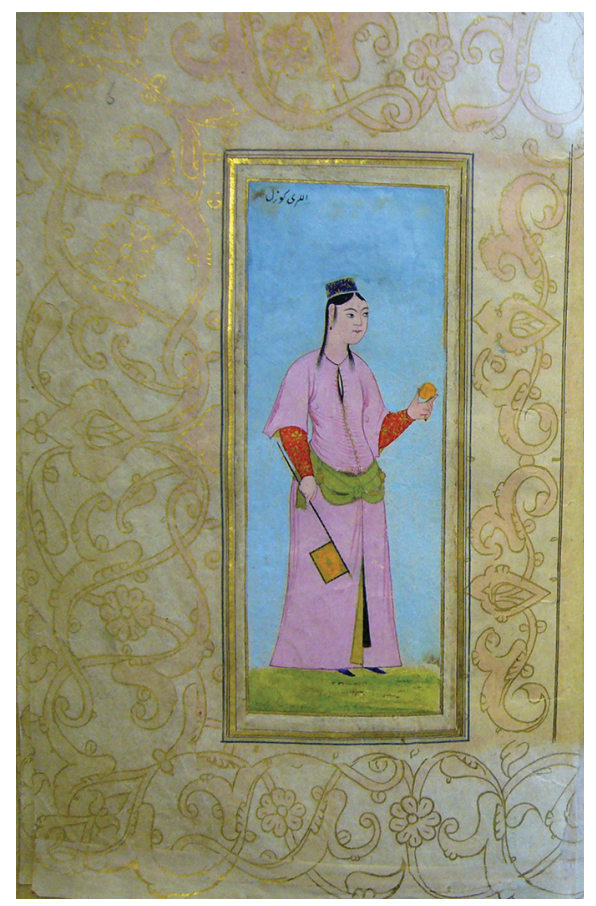

Resim 6. Albüm, Londra British Library, Or. 2709, v. 6a.

değinilen örnekteki kadın isimleri bu merakımızı bir nebze olsun gidermek için imdadımıza yetişir.

Osmanlı adet ve merasimleri hakkındaki kendi zamanına kadar ulaşmış bilgileri derleyerek kültür tarihimize eşsiz bir katkı sunan Abdülaziz Bey (18501918) İstanbul'un farklı kesimlerini anlatırken "Alüfteler" başlığı altında "yolunu şaşırmış" kadınlardan bahseder. Bunların ayırt edici özelliklerinden biri de kullandıkları isimlerdir. Bu tür kadınların genellikle neşeli isimler -çiçek isimleri gibikullandığını söyleyen Abdülaziz Bey uzunca da bir isim listesi verir. Ardından da genellikle isimlerine birer sıfat eklenerek çağrıldıklarını belirtir; mesela Benli Eda, Kartopu Şöhret ya da Kaymaktabağı Servet gibi. ${ }^{34}$ Görüldüğü gibi bu isimler bahsi geçen albüm resimlerindeki kadınların isimleri ile büyük bir benzerlik taşırlar; ayrıca da yukarıda zikredilen isimler de İstanbul hikâyelerinde adları geçen, genç ve güzel oğlanlarla çeşitli maceralar yaşayan cariyelerin isimlerini de andırırlar. ${ }^{35}$

34 Abdülaziz Bey, Osmanlı Âdet, Merasim ve Tabirleri, haz. Kazım Arısan-Duygu Arısan Günay, (İstanbul: Tarih Vakfi Yurt Yayınları, 2002), s. 331-332.

35 Cariye isimlerinin bolca anıldığı bir hikaye için bkz. Sayers, Tiflî Hikâyeleri, s. 212, 214. 
Bunlar belli ki toplum içinde isimleri ile bilinen, hikâyeleriyle meşhur kadınlardır; tıpkı genç erkekler gibi. Olasılıkla da albümlerde sıklıkla karşımıza çıkan bu kadınların ve İstanbul hikâyelerinde de sıkça karşımıza çıkan genç cariyelerin aynı kişiler olduğunu düşünmek mümkündür.

İlginç bir 16. yüzyıl şehrengizi ise bu düşüncenin haklıllğını epeyce kuvvetlendirir. Şehrin güzellerinin ve güzelliklerinin anlatıldığı şehrengizlerde kuşkusuz kadınlara pek yer verilmez. Azîzî (ö. 1585) tarafından yazılan ve Nigarnâme olarak da bilinen şehrengiz bu bakımdan hayli ilgi çekicidir; zira bu eserde İstanbul'un meşhur ve güzel kadınları anlatılmıştır. Burada anlatılan bazı kadınların isimleri, yukarıda bahsedilen albüm resimlerindeki kadınlarla çok benzerdir. Mesela, şehrengizde övgü ile anlatılan kadınlardan birinin adı Saçlı Zaman'dır ve bu güzel kadın şöyle tarif edilir:

"Biri mahbubenün Saçlı Zamandur / Kati çok yaşlu fettân-ı cihandur Zamâne gibi cevvâr u sitem-kâr / Saçınun sağışı âşıkları var

Alur dil kişverinden zülfi bâcı / Beni başdan çıkardı iki saçı”36

Aynı şehrengizde bahsi geçen bir diğer kadın olan Elleri Güzel Cemile ise şöyle anlatılır:

"Birisi elleri güzel Cemîle / Ki benzer hüsnile hûr-1 cemîle

Nice irsün meh anun pâyesine / Ki su koymağa değmez âyesine

Beni yâd idüp eyler illeri yâd / Elinden ol nigârın dâd u feryad" ${ }^{\text {"37 }}$

Görüldüğü üzere biri saçının diğeri ise ellerinin güzelliği ile meşhur olan bu iki kadın ve eserde benzer adlara sahip niceleri İstanbul'un eğlence hayatında tanınmış ve "hafifmeşrep" olarak algılanan hanımlardan olmalıydılar. Tıpkı yukarıda tasvirlerine değinilen Saçlı Raziye ve Elleri Güzel gibi. Nitekim, kamusal alanda görünür olması pek hoş karşılanmayan "saygın" bir Osmanlı kadının tasvirlere konu olması da zaten beklenemezdi.

$\mathrm{Bu}$ tür rahat kıyafetler bir yana, albümlerde kamusal alana uygun kıyafetlerle tasvir edilmiş, "sıradan" bir Osmanlı kadını gibi görünen bazı kadınların da "alüfte/aşüfte" olarak tanımlanan kesimden olduğu anlaşılır. 18. yüzyılın meşhur nakkaşı Levnî tarafından yapılan portrelerden oluşan bir albüm içinde yer alan bazı resimler bu konuda ilginç detaylar sunar. Belirli hikâyelerin kahramanları

36 Agâh Sırrı Levend, Türk Edebiyatında Şehr-Engizler ve Şehr-Engizlerde İstanbul (İstanbul: İstanbul Fethi Derneği, İstanbul Enstitüsü Yayınları, 1957), s. 124.

37 A.g.e. s. 130. 
olduğu düşünülen bu figürlerin isimleri ve meslekleri çoğunlukla sayfa üzerine not edilmiştir. ${ }^{38} \mathrm{Bu}$ tasvirlerden birinde feraceli ve peçeli bir kadın sokağa uygun giysiler içinde tasvir edilir. Kimliği hakkında bilgi veren yegane unsur, bir elinde tuttuğu bahar dalları ve üzerinde not edilmiş olan ismidir. Bu nota göre, tasvirdeki kadının ismi Menekşe Tûtî'dir; tıpkı "alüftelerin" kullandığı neşeli isimler gibi (Resim 7). Bu kadın da mı acaba "hafifmeşrep" kabul edilenlerdendi? Benzer bir giysi ile tasvir edilen bir başka kadının üzerindeki not ise bu tahmini doğrular; bu sefer notta şöyle yazar: "Bursa'nın 'âşuftesinin tebdîl tasviridir" (Resim 8). Bu not açıkça gösterir ki hem Menekşe Tûtî hem de bu kadın her ne kadar kamusal alana uygun giysilerle betimlenseler de Osmanlı toplumu tarafından alüfte ya da aşüfte kabul edilen kadınlardandır.

Bu örneklerin düşündürdüklerini kısaca toparlamak gerekirse; "saygın” kabul edilen Osmanlı kadınlarının kamusal alandan ve bu alanın görsel temsilinden uzak tutulduğu; buna karşılık daha çok şehrin eğlence sektöründe var olan ve "ahlaken makbul bulunmayan" kadınların -bu gruba gayrimüslimleri de eklemek mümkünhem ismen hem de cismen tasvirlerde var olabildiklerini düşünmek mümkündür. Bu durumda, albümlerde karşımıza çıkan bu kadınların da tıpkı genç erkekler gibi gerçek hayattan ilham alınarak yaratılmış "tipler", belirli hikâyeleri olan kimseler olduğunu varsayabiliriz. Bu varsayım, kadın tasvirlerindeki bazı detaylara daha dikkatli bakınca da yeni fikirlere olanak sağlar.

\section{Küçük Nesnelerle/de Gizlenen Öyküler}

Günümüze ulaşan tereke defterleri gösteriyor ki, Osmanlı kentlileri arasında statüyü işaret eden lüks ve gösteriş, daha çok kıyafet ve silah gibi nesneler üzerinden sergileniyordu. ${ }^{39} \mathrm{Bu}$ durum, tasvirlerde gördüğümüz her türlü detayın, daha dikkatli bir şekilde düşünülmesini zaruri kılar. Bu durumda, bu yazının konusu olan albüm resimlerindeki genç erkek ve kadınların taşıdıkları nesneler ve kıyafet ayrıntıları; bugünün izleyicisine çok da manalı gelmeyen ayrıntılar ve de tabii ki vücut dilleri çağdaşı olan izleyicilere pek çok şey ifade ediyor, küçük bir detay nice hikayeler anlatıyor olmalıydı. Öncelikle genç erkeklerin taşıdıkları kitaplar daha önce de değinildiği gibi onların edebi yeteneklerine, edebiyat meclislerindeki vazgeçilmez konumlarına; yine bellerinde taşıdıkları hançer, kama gibi nesneler

38 Gül İrepoğlu, Levni-Nakış Şiir Renk (İstanbul, 1999), s. 168, 178-181.

39 Uğur Tanyeli, “Osmanlı Metropollerinde Evlerin Konfor ve Lüks Normları,” Soframız

Nur Hanemiz Mamur, Osmanl Maddi Kültüründe Yemek ve Barınak, ed. Suraiya Faroqhi- Christoph Neumann (İstanbul: Kitap Yayınevi, 2006), s. 346-347. 
TÜLÜN DEĞİRMENCİ

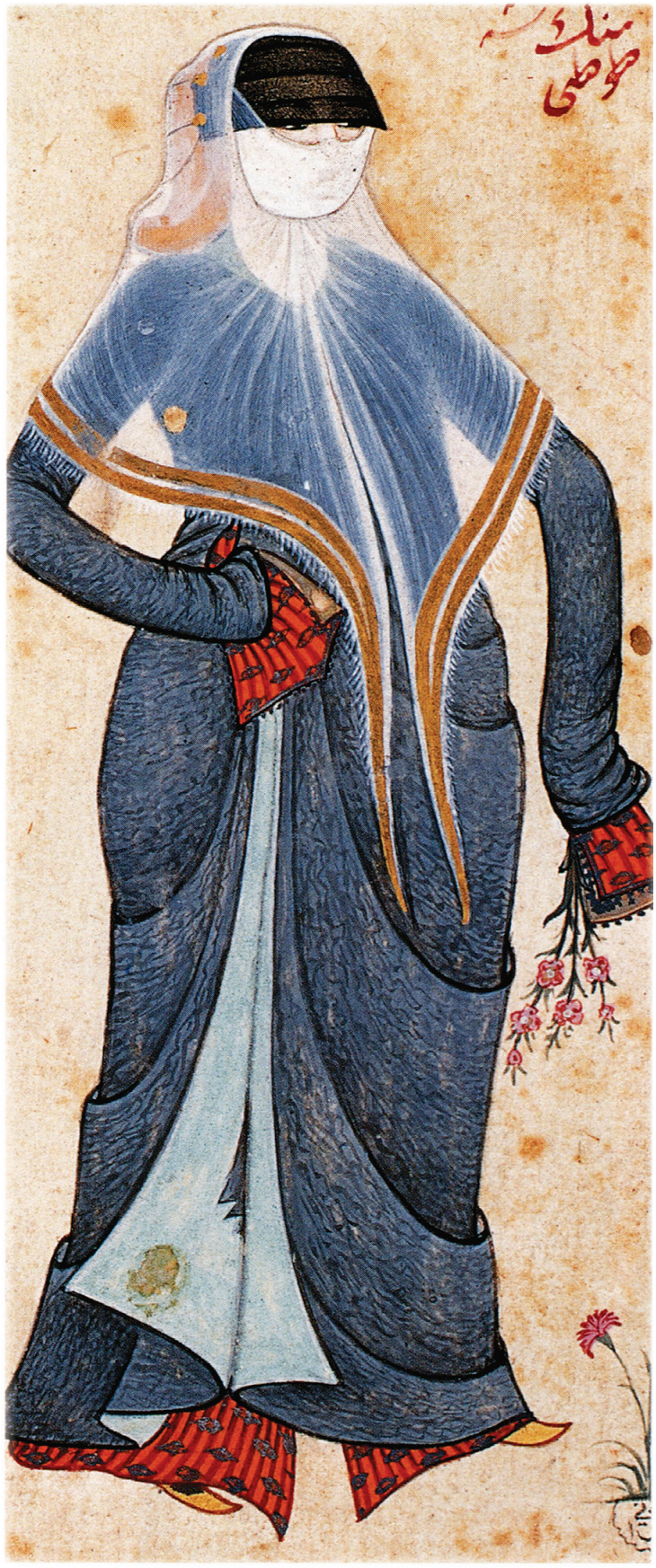

Resim 7. Levnî, Albüm, TSMK, H. 2155, v. 7a (İrepoğlu 1999)

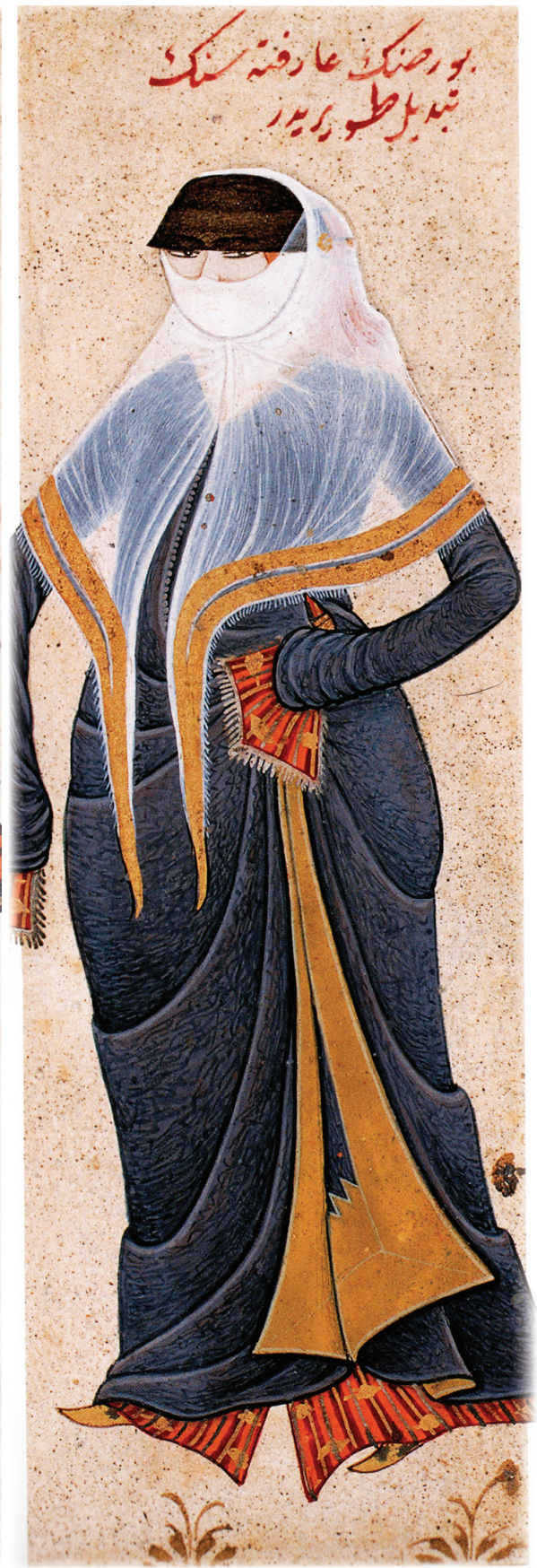

Resim 8. Levnî, Albüm, TSMK, H. 2155, v. 5b (İrepoğlu 1999) 
bıçkın mizaçlarına göndermeler yapıyor olmalıydı. Benzer bir şekilde kadın tasvirlerine de bakıldığında, bazı kadınların ellerinde tuttukları yemiş ya da meyveye benzer nesneler acaba birer işaret miydi?

İlişkilerin açık ve yüz yüze olmadığı bir toplumdu Osmanlı. 17 ve 19. yüzyıllar arasında aşıkların duygularını anlatmak için olağanüstü bir kriptik dil geliştirdikleri bilinmektedir. Bu dilde çok çeşitli objeler, renkler aşkın ifadesi olan birer simgeye dönüşmüştür. Mesela, eğer bir aşık maşukuna ceviz yollarsa bunun manası "niye bana eziyet ediyorsun" demektir. Sevgilisi buna bir fistıkla karşılık verirse, "sana kırıldım" demek istemiştir. Şayet bir parça demir yollarsa bunun anlamı da "ben erirken sen parliyorsun" demektir. ${ }^{40}$ Kim bilir belki de tasvirlerde gördüğümüz bu nesnelerin her biri tıpkı kitaplar gibi örtülü ya da açık pek çok anlama, hikâyeye tekabül ediyordu. Her bir detay resmin içine hapsolmuş ya da kodlanmış küçük hikayelerdi. Kadınların ellerinde tuttuğu meyve, kadeh ya da şişe gibi nesneler onların ait olduğu dünyanın imgelerle anlatımıydı. Zira 16. yüzyıl sonunda yapılmış bir tasvir, bu "günahkar" grubu ve de "günah" nesnelerini bir kontekst içinde apaçık gösteriyordu.

Kıyamet alametlerinin anlatıldığı Tercüme-i Miftâh-ı Cifru'l-Câmi (15951600) adlı eserde, kıyametin işaretlerinden biri de Allah'ın yeryüzüne göndereceği mülayim bir yelin esmesidir. Buna göre, kıyamet kopmadan hemen önce esecek olan bu yel, iyi Müslümanların ölümüne neden olacak, böylece kıyamet sadece kötü ve günahkarların üzerine kopacaktır. ${ }^{41}$ İşte metnin bu bölümünde yer alan tasvir konumuz açısından oldukça ilginçtir, çünkü günahkarları temsil etmek üzere betimlenen kişiler bu yazının da kahramanı olan genç erkek ve kadınlardır. Tasvirde, kırda müzik eşliğinde şarap içerek eğelenen bir grup genç kadın ve erkek tasviri görülür. Genç ve sakalsız olarak betimlenen erkeklerden biri elindeki küçük bir meyveyi meclisteki kadınlardan birine sunarken, aynı kadın elindeki şişeden doldurduğu kadehi bir başka genç erkeğin boynuna doğru dökmektedir (Resim 9). "Günahın" ve "günahkârların" portresi olarak tasarlanan bu tasvir, bir yandan bu gençlerin toplum tarafından algısını netleştirirken diğer yandan da albüm tasvirlerinde bağlamından yoksun şekilde karşımıza çıkan bazı nesnelerin olası anlamlarına ışık tutmaktadır. Yani bu durumda, yukarıda değinilen Saçlı Raziye'nin yahut da Elleri Güzel'in tuttukları küçük meyveler aşıkların arasındaki simgesel dilin imgelere dökümüydü. Aynı zamanda da tasvirdeki kadınların

40 Kafadar, "Women in Seljuk and Ottoman Society..." s. 198

41 TSMK, B. 373; Bahattin Yaman, "Osmanlı Resim Sanatında Kıyamet Alametleri: Tercüme-i Cifru'l-Cami ve Tasvirli Nüshaları”, Yayımlanmamış Doktora Tezi (Ankara: Hacettepe Üniversitesi, 2002), s. 148-149. 


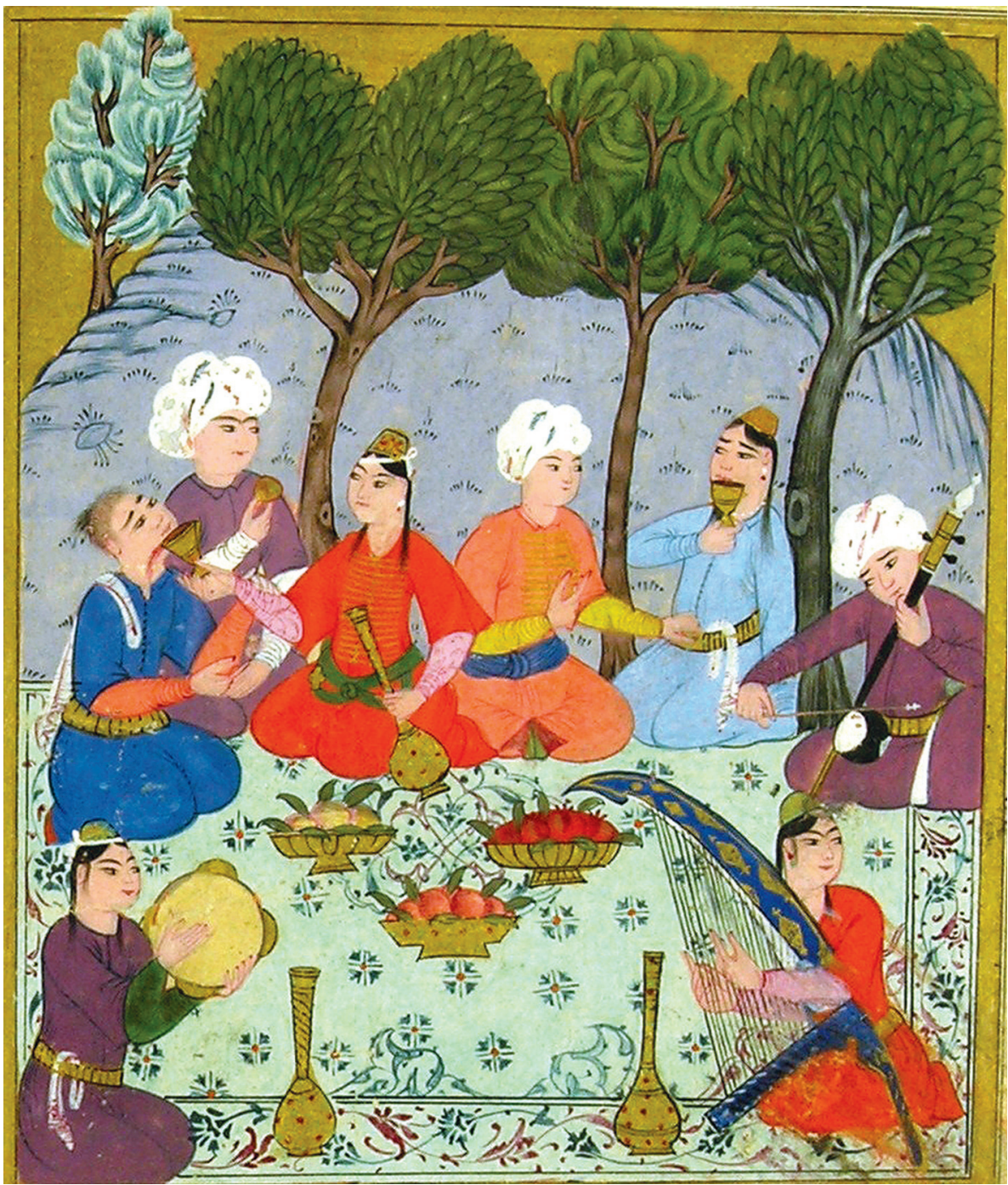

Resim 9. Tercüme-i Miftâh-ı Cifru'l-Câmi, TSMK, B. 373, v. 243b (Yaman 2002).

kimliğini inşa eden imge kalıplarıydı. Bu kalıplardan ya da simgelerden biri de kimi kadınların ayaklarındaki nalınlar olabilir miydi?

Albümlerdeki bazı kadınların ayaklarında hamamda giyilen nalınların olduğu görülür. ${ }^{42}$ İlginç olan ise bu kadınların hamamda tasvir edilmezken hamam-

42 Bu ayrıntıya dikkatimi çekerek konu üzerinde düşünmeme vesile olan Oya Pancaroğlu’na teşekkür ederim. 
da giymeye mahsus bir kıyafet ayrıntısı ile betimlenmeleridir. Nitekim, hamam sahneleri ya da hamama giden kadın portreleri Osmanlı resim sanatında hem Osmanlı hem de batılı ressamlar tarafından sıklıkla işlenen temalar arasındadır. ${ }^{43}$ $\mathrm{Bu}$ tasvirlerde çoğunlukla hamam kültürüne ve yaşantısına ait bireylerin farklı anları gösterilirken, burada konu edinilen albüm tasvirlerinde nalınlar "anlamlı" oldukları kontekstlerinden çıkarılmış, bir doğa parçası içinde gösterilen kadının ayaklarında karşımıza çıkmıştır. Böylece nesnenin kendi bağlamındaki anlamı yok edilmiş, ya da belki de yeni bir anlam üretilmiştir. Zira, bu kıyafet detayının ilk olarak çağrıştırdığı hamam, bir mekan olarak Osmanlı kadınlarının hayatında hijyen ihtiyacını karşılamanın çok daha ötesinde işlevler ve anlamlar taşımaktaydı.

Osmanlı kadınlarının evin sınırlarını aşarak sosyalleşme imkanı buldukları nadir mekanlardan biriydi hamam. Pek çok kadın haftada en az bir kez gittiği hamamda ailesi ve kendi sosyal çevresi dışındaki insanlarla iletişim kurma şansı ediniyordu. Burası sadece yıkanma yeri değil aynı zamanda bir sosyalleşme ve eğelenme mekanıydı; şehirdeki son havadisler alınıyor, oğullar için kız bakılıyordu. Özellikle pek çok insanın etrafında toplandığı göbek taşı, haberlerin ve bilgilerin yayıldığ 1 bir tür halk forumu işlevi görüyordu. ${ }^{44}$ Kuşkusuz benzer bir sosyalleşme erkekler için de geçerliydi. Nitekim İstanbul hamamlarında çılgın mirasyedilerin hamam kapatarak yaranı, avenesi ve dalkavukları ile soyunarak sofalarda işret sofraları kurdurttukları, göbek taşında köçek oynattıkları söylenenler arasındaydı. İstanbul hamamları için yazılmış destanlarda da göbek taşı üzerinde geçen aşklara, yapılan sohbetlere yapılan göndermeler, bu bölümün kentlilerin yaşamındaki önemini gözler önüne serer niteliktedir:

Fındıklıda Müftü Hamamı

Ey yârânı safâ, meşreb yoldaşı

Pâzârı hüsündür bu göbek taşı

Okunur "Meşâkı Uşşâk" kitâbı,

Cem olub güzeller, ilim erbâbı. ${ }^{45}$

43 Günsel Renda, "Ressam Gözüyle Osmanlı Hamamı,” Anadolu Medeniyetlerinde Hamam Kültürü: Mimari, Tarih ve İmgelem, der. Nina Ergin, çev. Ayşe Özbay Erozan (İstanbul: Koç Üniversitesi Yayınları, 2012), s. 369-403.

44 Artan, "Forms and Forums...", s. 386-387; Kafadar, "Women in Seljuk and Ottoman Society...,", pp. 200-203.

45 Reşat Ekrem Koçu, "Göbektaşı”, İstanbul Ansiklopedisi, 11 (1971), s. 7060-7061. 
Hamamlarda her ne kadar kadın ve erkek bölümleri fiziksel olarak birbirinden ayrılsa da, aslında hamam her iki cinsin aktarma noktası ya da geçiş alanı olarak kullandığı nadir mekanlardandı. ${ }^{46}$ Dolayısıyla bu iki cinsin karşılaşmasından doğacak her türlü "problem" için potansiyel mekanların da başında geliyordu. Özellikle de 16. yüzyılın ikinci yarısından itibaren İstanbul'a başlayan yoğun göçle şehrin sosyo-kültürel yapısında önemli değişimler yaşanmıştı. Bu değişimde, hamamlar diğer kamusal mekanlarla birlikte yeni işlevler üstlenen, makalenin girişinde de vurgulandığı gibi, farklılaşan iletişim biçimlerine göre yeniden şekillenen kamusal mekanların başında geliyordu.

Osmanlı tarihi üzerine yapılan çalışmalar gösteriyor ki, 16. yüzyıl ortalarından itibaren İstanbul'un nüfusu epeyce kalabalıklaşmaya başlar. Daha iyi bir hayat ümidiyle 16. yüzyılda başlayan akın, 1600'lerden itibaren Anadolu'da Celali ayaklanmalarının neticesinde iyice artar. ${ }^{47}$ Anadolu’dan gelen bu işsiz güçsüz genç kitle hem İstanbul'da sorun yaratmış hem de nüfusu azalan köyler vergi yükü altında ezilmeye başlamıştır. Bu sebeple 1635 'te IV. Murad İstanbul'da en az kırk yıl yerleşik halde olmayanların geri dönmesini emretmiştir. ${ }^{48}$ 18. yüzyıldaki "Malikâne" sistemi sonucu uygulanan ağır vergiler ise taşra kaynaklı göçleri daha da hızlandırmıştır. ${ }^{49}$ Bu yoğunlaşma İstanbul'a göçü engellemeye yönelik pek çok fetvanın yazılmasına sebep olmuştur. ${ }^{50}$

Tüm bu yasaklamaların başlıca nedeni, kuşkusuz, İstanbul'da göçün yarattığı pek çok ekonomik ve sosyal sorun baş göstermeye başlamasıdır. Özellikle yeni gelen genç ve bekar nüfusun kontrol altına alınması, 17. yüzyıldan itibaren Osmanlı yöneticilerinin önemli sorunlarından bir olmuşa benzemektedir. Çoğunlukla bekar odalarında kalan, geçici işlerde çalışan ve şehrin sosyal dokusuyla uyum sorunu yaşayan bu gençlerin çok sayıda suça karıştığı bilinmektedir. Mesela, 1763 tarihli Üsküdar mahkemesi kadı siciline dayanılarak yapılan bir çalışmada, şiddet

46 Artan, "Forms and Forums...", s. 380. ?

47 Suraiya Faroqhi, "Migration into Eighteenth-Century 'Greater İstanbul' as Reflected in the Kadı Registers of Eyüp," Turcica, 30 (1988), s. 163-183.

48 Hrand D. Andreasyan, "Celâlilerden Kaçanların Geri Gönderilmesi,” Ord. Prof. İsmail Hakkı Uzunçarşılıya Armăgan, (Ankara: Türk Tarih Kurumu Basımevi, 1988), s. 45-53.

49 Cengiz Şeker, "The Causes of Rural Migrations in the $18^{\text {th }}$ Century Ottoman Society," The Journal of Ottoman Studies, guest editor: Seyfi Kenan 42 (2013), s. 207-231.

50 M. Münir Aktepe, “XVII. Asrın ilk Yarısında İstanbul'un Nüfus Mes'elesine dair bazı Vesikalar,” İstanbul Üniversitesi Edebiyat Fakültesi Tarih Dergisi, IX/13 (Eylül 1958), s. 1-30. 
ve hareketlilik arasında yoğun bir ilişki olduğu gözlenmiştir. Kent içinde geçici ikamet bölgelerinde -iskeleler, ticaret alanları gibi- sosyal ilişkilerin daha yaygın, buna karşılık "kural dışılığın" da daha fazla olduğu bilinmektedir. Bu bölgeler fuhuş, şiddet gibi suçlarla ilgili şikâyetlerin yoğunlaştı̆̆ı yerlerdir. Sadece mekâna göre değil, meslek gruplarına göre de suç oranlarında artış izlenmiştir. Mesela iskelede çalışan kayıkçılar, beygirciler gibi hareket yetisine sahip meslekler arasında suç oranları daha yüksektir. Bu meslek grupları çoğunlukla taşradan göç etmiş, bekar odalarında yaşayan ve kentte geçici ya da yabancı sakinler olarak görülen kişiler tarafından yapılmaktadır. Tabii ki bu kesim arasında suç oranlarının artışında, en fazla suç işleyen zümre olmaları değil de kentte yabancı ve "gariban" olarak görüldüklerinden bunlarla ilgili şikayetlerin kadı sicillerine daha kolay yansımış olma ihtimali de gözardı edilmemelidir. ${ }^{51}$ Hamamlarda çalışan ve genellikle yakışıklı ve bekar gençlerden müteşekkil zümreyi de bu gruba dahil edebiliriz. Hamamların işleyişi ile ilgili belgelere bakıldığında, daha çok genç ve yakışıklı delikanlılardan oluşan hamam çalışanlarının kontrol altına alınmaya çalışıldığı izlenir. ${ }^{52}$

Bir 17. yüzyıl tarihçisinin naklettiği bazı bilgiler hem bu genç nüfusun şehirde yarattığı "rahatsızlığı" hem de hamamların kentin sosyal yaşamındaki rolünü daha net bir şekilde görmemizi sağlar. Mehmed Halife, 1632 yılında kul taifesinin "azgınlıklarını" "gündüz hamamdan peştamal ile çıplak avrat çıkarmak", Sultan Mehmed Camisi'nde tütün içmek, ev ve saray basmak, kahvehane ve meyhanelerde her türlü uygunsuz işi yapmak olarak sıralıyordu. ${ }^{53}$ Şehrin periferisinde yaşayan bekar taifesinin karıştığı cinsel suçlar, hatta bu sebeple hamamda öldürülen bir gence ait kayıtlar dönemin başka belgelerine de yansımıştı. Bunun dışında hem hamam yolunda hem de hamamda kadınların ve erkeklerin karıştığı asayişle ilgili

51 Işık Tamdoğan, "Atı Alan Üsküdar'ı Geçti ya da 18. Yüzyılda Üsküdar'da Şiddet ve Hareketlilik İlişkisi,” Osmanlida Asayiş, Suç ve Ceza, 18. -20. Yüzyıllar, der. Noémi Lévy ve Alexandre Toumarkine, (İstanbul: Tarih Vakfı Yurt Yayınları [tarihsiz]), s. 80-95.

52 Nina Ergin, “İstanbul'da Hamam İşletmeciliği: On Yedinci ve On Sekizinci Yüzyılda Çemberlitaş Hamamı,” Anadolu Medeniyetlerinde Hamam Kültürü: Mimari, Tarih ve İmgelem, der. Nina Ergin, çev. Ayşe Özbay Erozan (İstanbul: Koç Üniversitesi Yayınları, 2012), s. 181-189.

53 Mehmed Halife, Tarih-i Gılmani, haz. Ömer Karayumak (İstanbul: Tercüman 1001 Temel Eser, [tarihsiz]), s. 28. Yeniçerilerin On Yedinci Yüzyıl İstanbulu'nun sosyal yaşamındaki rolü hakkında güncel bir çalışma için bkz. Gülay Yılmaz, "The Economic and Social Role of Janissaries in a $17^{\text {th }}$ Century Ottoman City: The Case of Istanbul", Yayınlanmamıss Doktora Tezi (Montreal: McGill University, 2011). 
pek çok olaya ve devletin kontrolü sağlamak üzere yaptığı uygulamalara dair bilgilere çeşitli Osmanlı kaynaklarında rastlamak mümkündür. ${ }^{54}$

Tekrardan albüm resimlerinde kadınların ayaklarında görülen nalınlara dönersek, bu kıyafet detayı sıradan bir seçimden ziyade, bu kadınların kentin sosyal hayatında var olabildikleri yegane mekan olan hamamla ilişkilerine ve bu mekanlardaki rollerine göndermeler yapan kodlar olarak okunabilir. Tipkı tasvirlerdeki kadınların ve erkeklerin ellerinde tuttuğu kitap, çiçek, hançer ya da meyveler gibi.

Kısaca çizilmeye çalışılan bu sosyal-kültürel bağlam gösteriyor ki albümler ve mecmualar içinde sıklıkla karşımıza çıkan ve bazı örneklerine yukarıda değinilen genç portreleri 17. yüzyılla birlikte sosyolojik bir grup olarak öne çlkan, çoğunlukla bekarlardan oluşan bu gençlerin ve onların türlü maceralar yaşadığı güzel kadınların imgelere dökülmüş hikayeleri gibidir adeta. Bu tasvirlerde gençlerin ellerinde tutukları kitap, çiçek, meyve gibi nesneler, taşıdıkları objeler ya da daha bütüncül olarak "kıyafetleri” İstanbul'un sokaklarında geçen/geçtiğine inanılan hikâyelerindeki gerçek ya da kurgu olan rollerine göndermeler yapan simgeler olmalıydı. Resmi kayıtlarda suçun ve suçluların çoğaldığı, şehrin adeta "karanlık sokakları" olarak algılanan bu mekanlar ve onların sakinleri aynı zamanda "orta sınıf” şehir/şehirli kültürünün de yaşam alanı olmalıydı. Bu durumda, günümüzden bakıldığında sadece belirli "kalıpları" ya da "stereotipleri" tekrar eder gibi görünen pek çok resmi, bu tarihsel bağlam içinde, yeni gelişen toplumsal yapının aksettiği bir "medya" alanı gibi okumak mümkündür. Tıpkı basit bir eğlenme aracının dışında sosyal tarihin içine dokunduğu, şehrin farklı mekanlarında dolaşan ve de bir tür "halk forumu" işlevi gören popüler hikayeler gibi, bu tasvirler de benzer tartışmaları çağdaş okuyucularına imleyen görüntüler olmalıydı. Ve olasılıkla da, çağdaşı olan izleyicileri için, genç kadın ve erkeklerden ziyade pek çok hikayeyi içeren "görsel anlatılardı."

54 Bu tür olayların bir derlemesi için bkz. Ebru Boyar-Kate Fleet, Osmanl İstanbul'unun Toplumsal Tarihi, çev. Serpil Çağlayan (İstanbul: Türkiye İş Bankası Kültür Yayınları, 2014), s. 279-287. 
Osmanl Tasvir Sanatında Görselin "Okunması”: İmgenin Ardındaki Hikâyeler (Şehir Oğlanları ve Istanbul'un Meşhur Kadınlari)

Öz — Başlıca amacı eşlik ettiği metni görselleştirmek olan İslâm kitap resimlerinin en belirleyici özelliklerinden biri imge ve metin arasındaki organik ilişkidir. Bunun dışında herhangi bir metne eşlik etmeyen tek yaprak albüm/murakka resimleri de İslâm tasvir sanatı geleneğinde epeyce yaygın bir şekilde karşımıza çıkar. Yazılı bir metnin bağlamından yoksun murakka resimlerini anlamak, yani imgenin çağdaş izleyicileri tarafından görülme/algılanma biçimine yaklaşmak için tasvirin yaratıldığı ve tüketildiği toplumun sözlü ve/veya sözel kültüründen yola çıkılarak bir "görsel okuma” kavramının geliştirilmesi elzemdir. Nitekim, bu sözel bağlam, imgeyi oluşturan ve bugünden bakıldığında "sıradan" görünen pek çok ikonografik ayrıntının çağdaş izleyicileri için belirli öykülere tekabül eden kodlamalar olduğunu gösterecektir. Bu yazıda çoğunlukla 17. yüzyılda Osmanlı İstanbul'unda üretilmiş, belirli genç erkek ve kadınları betimleyen bir grup albüm resminden yola çııılarak, bu imgelerin oluşumunda etkili olan sözel bağlam üzerinde durulacaktır. Özellikle 17. yüzyılla birlikte Osmanlı İstanbul'unun değişen demografik yapısı ve bunun sonucunda ortaya çıkan yeni sosyalleşme mekanları, bu mekanlarda değişen iletişim biçimleri ile tasvirlerin bu yeni iletişim biçimlerine göre uğradığı biçim ve içerik değişimleri arasındaki bağ bu tartışmanın ana eksenini oluşturacaktır.

Anahtar kelimeler: Osmanlı Elyazmaları, 17. Yüzyıl Osmanlı Tarihi, Albüm Resimleri, Minyatür, Şehir Oğlanları, Cariyeler

\section{Kaynakça}

\section{Yazma Eserler}

Hikâyât-ı Sipâhî-yi Kastomonî ve Tûtî, Millet Kütüphanesi, Ali Emiri, Roman 146.

Mısır Vâlisi Koca Cafer Paşa’nın Hikâyesi, Süleymaniye Kütüphanesi, Hacı Mahmud Efendi No. 6264.

\section{Yayınlar}

Abdülaziz Bey, Osmanl Âdet, Merasim ve Tabirleri, Kazım Arısan-Duygu Arısan Günay (haz.), İstanbul: Tarih Vakfı Yurt Yayınları 2002.

And, Metin: "17. Yüzyıl Türk Çarşı Ressamları," Tarih ve Toplum 6 (1985), s. 40-45. "17. Yüzyıl Türk Çarşı Ressamlarının Padişah Portreleri,” Türkiyemiz 58 (1989), s. $4-13$.

Aktepe, M. Münir: “XVII. Asrın ilk Yarısında İstanbul'un Nüfus Mes'elesine dair bazı Vesikalar," İstanbul Üniversitesi Edebiyat Fakültesi Tarih Dergisi, IX/13 (Eylül 1958), s. $1-30$. 
Andreasyan, Hrand D.: "Celâlilerden Kaçanların Geri Gönderilmesi," Ord. Prof. İsmail Hakkı Uzunçarşılıya Armağan, Ankara: Türk Tarih Kurumu Basımevi 1988, s. 45-53.

Artan, Tülay: "Forms and forums of expression: İstanbul and beyond, 1600-1800," The Ottoman World, Christine Woodhead (ed.), New York: Routledge 2012, s. 378-405.

Assman, Jan: Kültürel Bellek. Eski Yüksek Kültürlerde Yazı, Hatırlama ve Politik Kimlik, Ayşe Tekin (çev), İstanbul: Ayrıntı Yayınları 2001.

Bağc1, Serpil: "Presenting Vassal Kalender's Works: The Prefaces of Three Ottoman Albums," Muqarnas, 30 (2013), s. 255-313.

Boratav, Pertev Naili: Halk Hikâyeleri ve Halk Hikâyeciliği, İstanbul: Adam Yayınları 1988.

Boyar, Ebru ve Kate Fleet: Osmanlı İstanbul'unun Toplumsal Tarihi, Serpil Çağlayan (çev.), İstanbul: Türkiye İş Bankası Kültür Yayınları 2014.

Buzov, Snjezana: “Osmanlı'da karışık içerikli mecmûalar: bir başka arşiv,” Türk Edebiyatı Çalışmaları VII, Mecmûa: Osmanlı edebiyatının kırkambarı, H. Aynur, M. Çakır, H. Koncu, S. Kuru, A. E. Özyıldırım (haz.), İstanbul: Turkuaz 2012, s. 33-42.

Değirmenci, Tülün: "An Illustrated Mecmua: The Commoners Voice and the Iconography of the Court in Seventeenth-Century Ottoman Painting," Ars Orientalis, 41 (December 2011), pp. 187-218.

Düzdağ, M. Ertuğrul: Şeyhülislâm Ebussû̂d Efendi Fetvaları Işı̆̆ında 16. Asır Türk Hayatı, İstanbul: Enderun Kitabevi 1983.

Gelibolulu Mustafa 'Âlî: Mevấidü’n-nefäis fî-Kavâ'idi'l-mecalis, Mehmet Şeker (ed.) Ankara: Türk Tarih Kurumu Yayınları 1997.

Ergin, Nina: "İstanbul'da Hamam İşletmeciliği: On Yedinci ve On Sekizinci Yüzyılda Çemberlitaş Hamamı," Anadolu Medeniyetlerinde Hamam Kültürü: Mimari, Tarih ve Imgelem, Nina Ergin (der.), Ayşe Özbay Erozan (çev.), İstanbul: Koç Üniversitesi Yayınları 2012, s. 182-209.

Faroqhi, Suraiya: "Migration into Eighteenth-Century 'Greater İstanbul' as Reflected in the Kadı Registers of Eyüp,” Turcica, 30 (1988), pp. 163-183.

Fentress, James ve Chris Wickham: Social Memory, Oxford: Blackwell Publishers, 1992.

Fetvac1, Emine: “The Album of Ahmed I,” Ars Orientalis, 42 (2012), pp. 127-138.

Kafadar, Cemal: "Sohbete Çelebi, Çelebiye mecmûa...", Türk Edebiyatı Çalışmaları VII, Mecmûa: Osmanlı edebiyatının kırkambarı, H. Aynur, M. Çakır, H. Koncu, S. Kuru, A. E. Özyıldırım (haz.) İstanbul: Turkuaz 2012, s. 43-52.

Kafadar, Cemal: "Women in Seljuk and Ottoman Society up to the mid-19th Century," Woman in Anatolia: 900 Years of the Anatolian Woman, İstanbul: Turkish Republic Ministry of Culture 1993, pp. 192-205.

Kortantamer, Tunca Nev'̂̀-zâde Atâyî̀ ve Hamsési, İzmir: Ege Üniversitesi Yayınları 1997. 
Kavruk, Hasan: Eski Türk Edebiyatında Mensûr Hikâyeler, İstanbul: Milli Eğitim Bakanlığ1 Yayınlar1 1998.

Koçu, Reşat Ekrem: “Göbektaş», İstanbul Ansiklopedisi, 11 (1971), s. 7060-7061.

Levend, Agâh Sırrı: Türk Edebiyatında Şehr-Engizler ve Şehr-Engizlerde İstanbul, İstanbul: İstanbul Fethi Derneği, İstanbul Enstitüsü Yayınları 1957.

İrepoğlu, Gül: Levni-Nakış Şiir Renk, İstanbul, 1999.

Majda, Tadeusz: “Rålamb’n Türk kıyafetleri Albümü,” Alay-ı Hümayun, İsveç Elçisi Rålamb’n İstanbul Ziyareti ve Resimleri, 1657-1658, Karin Ådahl (ed.), Ali Özdamar (çev.), İstanbul: Kitap Yayınevi 2006.

Minorsky, V.: The Chester Beatty Library, A Catalogue of the Turkish Manuscripts and Miniatures, Dublin: Hodges Figgis \& Co. Ltd 1958.

Mehmed Halife, Tarih-i Gılmani, Ömer Karayumak (haz.), İstanbul: Tercüman 1001 Temel Eser [tarihsiz].

Ong,Walter J.: Sözlü ve Yazılı Kültür, Sözün Teknolojileşmesi, Sema Postacıŏlu Banon, (çev), İstanbul: Metis Yayınları 2010.

Peirce, Leslie: "Ekberiyet, Cinsellik ve Toplum Düzeni: Modern Dönemin Başlangıcında Toplumsal Cinsiyetle İlgili Osmanlı Söz Dağarcığı,” Modernleşmenin Eşiğinde Osmanlı Kadınları, Madeline C. Zilfi (ed.), Necmiye Alpay (çev), İstanbul: Tarih Vakfi Yurt Yayınları 2009, s. 166-193.

Renda, Günsel: “Ressam Gözüyle Osmanlı Hamamı,” Anadolu Medeniyetlerinde Hamam Kültürü: Mimari, Tarih ve İmgelem, Nina Ergin (der.), Ayşe Özbay Erozan (çev.) İstanbul: Koç Üniversitesi Yayınları 2012, s. 369-403.

Renda, Günsel: “17. Yüzyıldan bir Grup Kiyafet Albümü,” 17. Yüzyıl Osmanlı Kültür ve Sanatı Sempozyumu Bildirileri, 19-20 Mart 1998, İstanbul 1998, s. 153-178.

Sariyannis, Marinos: "Mobs, Scamps and Rebels in Seventeenth-Century İstanbul," International Journal of Turkish Studies, 11/1-2 (2005), pp. 1-15.

Sayers, David Selim: Tiflî Hikâyeleri, İstanbul: Bilgi Üniversitesi Yayınları 2013.

Schick, Leslie Meral: "Meraklı Avrupalılar İçin Bir Başvuru Kaynağı: Osmanlı Kıyafet Albümleri," Toplumsal Tarih 116 (August 2003), s. 4-9.

Şeker, Cengiz: "The Causes of Rural Migrations in the $18^{\text {th }}$ Century Ottoman Society," Osmanlı Araştırmalar, The Journal of Ottoman Studies, guest editor: Seyfi Kenan 42 (2013), pp. 207-231.

Tamdoğan, Işık: “Atı Alan Üsküdar'ı Geçti ya da 18. Yüzyılda Üsküdar'da Şiddet ve Hareketlilik İlişkisi,” Osmanlida Asayiş, Suç ve Ceza, 18. -20. Yüzyıllar, Noémi Lévy ve Alexandre Toumarkine (der.), İstanbul: Tarih Vakfi Yurt Yayınları [tarihsiz], s. 80-95. 


\section{TÜLÜN DEĞİRMENCİ}

Tanyeli, Uğur: "Osmanlı Metropollerinde Evlerin Konfor ve Lüks Normları," Soframız Nur Hanemiz Mamur, Osmanlı Maddi Kültüründe Yemek ve Barnak, Suraiya FaroqhiChristoph Neumann (ed.), İstanbul: Kitap Yayınevi 2006, s. 333-349.

Titley, Norah M.: Miniatures from Turkish Manuscripts, A Catalogue and Subject Index of Paintings in the British Library and British Museum, London: The British Library 1981.

Yaman, Bahattin: “Osmanlı Resim Sanatında Kıyamet Alametleri: Tercüme-i Cifru’l-Cami ve Tasvirli Nüshaları”, (Yayımlanmamış Doktora Tezi) Ankara: Hacettepe Üniversitesi 2002.

Yılmaz, Gülay: "The Economic and Social Role of Janissaries in a $17^{\text {th }}$ Century Ottoman City: The Case of Istanbul”. Yayınlanmamış Doktora Tezi (Montreal: McGill University, 2011). 
